\title{
Instrumental Volcano Surveillance and Community Awareness in the Lead-Up to the 1994 Eruptions at Rabaul, Papua New Guinea
}

\author{
Chris McKee, Ima Itikarai and Hugh Davies
}

\begin{abstract}
Instrumental volcano surveillance and community awareness played key roles in preparing for the outbreak of the 1994 VEI 4 volcanic eruptions at Rabaul (pop. 17,000). The eruptions were preceded by 23 years of fluctuating unrest involving swarms of caldera earthquakes ( $\max M_{L}$ 5.2) and co-seismic uplift of parts of the floor of Rabaul Caldera. Eruption contingency planning was formally driven by government authorities and involved all sections of the community. Community awareness of the volcanic threat was enhanced by the dissemination of relevant information by the Public Information Unit of the East New Britain Provincial Government and reached a peak in the mid-1980s at the time of a large increase in the strength and frequency of earthquake activity (between August 1983 and July 1985). However, the intensity of the unrest declined after July 1985 and another 9 years elapsed before a new and dramatically stronger phase of unrest took place. The strong and sustained earthquake activity on 18 September 1994, together with marked co-seismic uplift that took place that night, was the final episode of volcanic unrest prior to the outbreak of eruptions on the morning of 19 September 1994. Memories and stories of the seismic prelude to the previous eruptions, in 1937, are reported to have been a major influence on community response
\end{abstract}

C. McKee $(\bowtie)$

Port Moresby Geophysical Observatory,

P.O. Box 323, Port Moresby, NCD,

Papua New Guinea

e-mail: chris_mckee@mineral.gov.pg

I. Itikarai

Rabaul Volcanological Observatory, P.O. Box 386,

Rabaul, ENBP, Papua New Guinea

H. Davies

Earth Sciences, University of Papua New Guinea,

P.O. Box 414 University NCD, Port Moresby, Papua

New Guinea

Advs in Volcanology (2018) 205-233

https://doi.org/10.1007/11157_2017_4

(C) The Author(s) 2017

Published Online: 12 April 2017 
to the seismicity on 18 September 1994. The evacuation of all areas within the caldera proceeded efficiently from late afternoon of 18 September until the early hours of 19 September. These areas were almost deserted when the eruptions started at two vents, Tavurvur and Vulcan, on opposite sides of the caldera at 0606 and 0717 LT respectively on the morning of 19 September 1994. Ten deaths in the first six weeks of eruptive activity were volcano-related. Damage inflicted by the eruptions was severe. About $70 \%$ of Rabaul Town was destroyed by tephra fall from Tavurvur, and several villages were obliterated by pyroclastic flows and heavy tephra fall from Vulcan. The 23 years of precursory activity and the events around the start of the 1994 eruptions delivered a number of important lessons in the fields of volcano surveillance, communications and disaster management. Perhaps the most important lessons of all are that co-existence with active and potentially active volcanoes requires (i) open and effective lines of communication between volcano scientists, government officials, town authorities and the general public, facilitated by designated public information officers, and (ii) the establishment and frequent exercising of eruption contingency plans.

\section{Introduction}

Rabaul is the name of both a complex volcanic system and a town at the northeastern tip of the Gazelle Peninsula, New Britain Island, Papua New Guinea (Fig. 1). Since the latest caldera-forming eruption at Rabaul, at about 1400 BP (Heming 1974; Walker et al. 1981), small cones have grown at five vent areas within Rabaul Caldera. The recorded eruption history of the Rabaul system spans a period of about 250 years and includes six eruptive episodes that took place at intervals of 24-59 years: 1767,1791 , 1850s, 1878, 1937 and 1994 (McKee et al. 2016). The most active vents during the historical period were those in the Vulcan area and at Tavurvur, on the western and eastern sides of Rabaul Caldera respectively (Fig. 1). These centres were simultaneously active in 1878, 1937 and 1994.

The town of Rabaul is one of very few towns or cities worldwide that has been built inside the caldera of an active volcanic system. The town was established within Rabaul Caldera by the German Administration of New Guinea in the period 1904-1910 (Johnson and Threlfall 1985), about 30 years after the 1878 eruptions (Brown 1878;
Johnson et al. 1981). The early German capital had been at Kokopo about $20 \mathrm{~km}$ southeast of Rabaul (Fig. 1), outside the caldera, but the seat of government was shifted to Rabaul in 1910. The attraction of the new site was the sheltered deep-water harbour. The tenure of Rabaul as the capital of German New Guinea was short-lived. In 1914, at the beginning of the First World War, Germany lost its New Guinea territory to an invasion of Australian forces. After World War I, administration of Rabaul, and indeed of New Guinea, became the responsibility of Australia.

The disastrous eruptions of May 1937, during which more than 500 lives were lost (Fisher 1939; Johnson and Threlfall 1985), led to broad-ranging investigations by the Australian Administration concerning the suitability of Rabaul as a capital city. There was disagreement about the future of the town. However, it was proposed that Rabaul could remain as the capital provided that a volcanological observatory was established to monitor the volcanoes and to warn of future eruptions. Routine volcanological observations at Rabaul commenced in 1938, and in 1940 the first Rabaul Volcanological Observatory (RVO) was established, at a site on the 


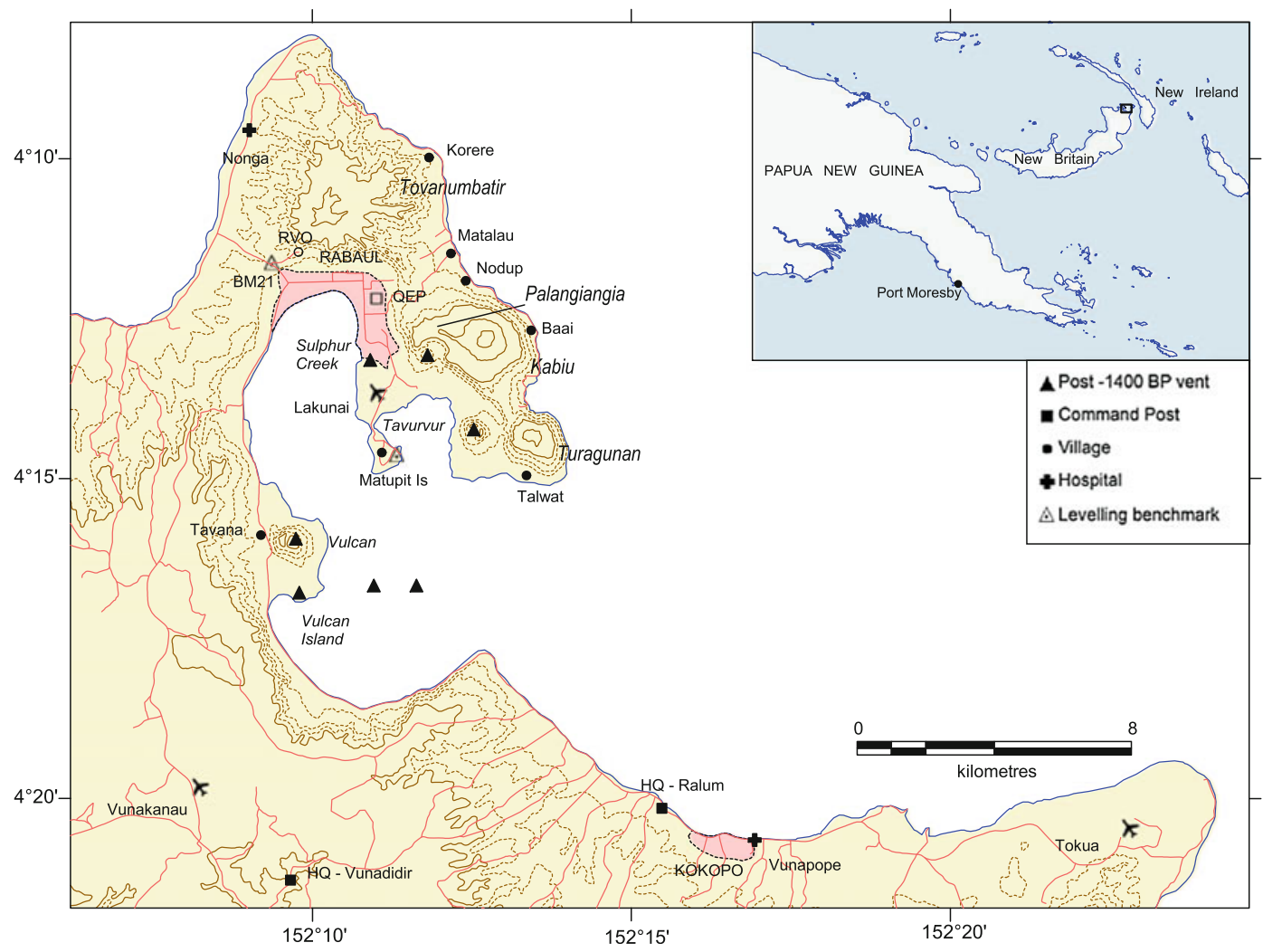

Fig. 1 The northeastern tip of the Gazelle Peninsula, New Britain Island, showing the major stratovolcanoes, post-1400 BP vents within Rabaul Caldera, the towns Rabaul and Kokopo, RVO, villages mentioned in the text, emergency command posts, hospitals, airports and the emergency assembly area, Queen Elizabeth Park (QEP).

northern rim of the caldera. The same site is occupied by the current RVO (Fig. 1). Following a resurgence of eruptive activity in June 1941 (Fisher 1976), a decision was made by the Administration in September 1941 to shift the capital to Lae on the New Guinea mainland, thus ending a period of 31 years in which Rabaul was a colonial capital.

Apart from suffering the effects of volcanic eruptions in the period 1937-1941, the town was totally destroyed by bombing during World War II, and substained about $70 \%$ destruction by volcanic activity in 1994 (Blong and McKee 1995; Davies 1995). Intermittent eruptions between 1994 and 2014 occasionally made life at Rabaul unpleasant.
Surveying benchmarks on the northwestern caldera rim (BM 21) and at Matupit Island mark the ends of the main levelling line. Inset map shows the islands of New Britain and New Ireland, and the capital city Port Moresby on mainland Papua New Guinea

Before the outbreak of the 1994 eruptions, the population of the town was about 17,000 . A much larger population of about 100,000 lived in the satellite towns, villages and plantations of the Rabaul-Kokopo area. The urban and, to a lesser extent, plantation communities contained a mixture of short- and long-term residents, while residents of the villages could be regarded as constituting traditional communities. Apart from Rabaul Town the most-threatened population centres within the caldera are at the villages Tavana (near Vulcan), Talwat (near Tavurvur) and Matupit Island (between Vulcan and Tavurvur), as shown in Fig. 1. These villages, and indeed all areas within Rabaul Caldera, are frighteningly close to sources of volcanic threat. 
The frequency of eruptions at Rabaul in the historical period, about 2 per century, has conditioned the traditional communities to the local volcanic threats. Local knowledge, particularly from the experience of the 1937 eruptions, coupled with the results of instrumental volcano monitoring and the long period of precursory activity (starting in 1971) resulted in a high level of volcano awareness prior to the 1994 eruptive outbreak. This awareness was an important element in the response to the volcanic unrest that preceded the 1994 eruptions.

The eruptive period that started at Rabaul in 1994 is important both as:

(i) a destructive event at a densely populated caldera volcano with a recent history of eruptions and caldera unrest-a case commonly identified as being a particular challenge for both monitoring and for warning communication, as in the context of Campi Flegrei, Italy, and Masaya, Nicaragua (e.g. Newhall and Dzurisin 1988).

(ii) an unusual case in which self-warning and evacuation of communities occurred in parallel with (and in some instances, in advance of) the formal volcano alert levels.

\section{Precursory Activity (I): 1971-1985}

\subsection{The Nature of Volcanic Unrest at Rabaul-Characteristics of Rabaul Volcanic Crises}

Historical records suggest that unrest between volcanic eruptions at Rabaul may be common, manifest as ground deformation and earthquakes. Uplift was reported to have occurred in the Sulphur Creek to Matupit Island area (see Fig. 1) in the lead-up to an eruption at Sulphur Creek in about 1850 (Brown 1878; Boegershauser 1937; Fisher 1939). Immediately prior to the 1878 eruptions that created Vulcan Island and formed a new crater at Tavurvur, small rocky islets near the site of the Vulcan Island eruption were raised about $1 \mathrm{~m}$ and massive uplift of $\approx 6 \mathrm{~m}$ occurred along the foreshore at the southern foot of Tavurvur (Brown 1878; Johnson et al. 1981). Frequent local earthquakes preceded the eruptions, and tsunami activity was reported but its timing is unclear (Brown 1878; Fisher 1939). An account of earthquake activity at Matupit Island in 1891 by Edward Hernsheim (Sack and Clark 1983) refers to continual earth tremors and subterranean rumblings heard by residents of the island (including Hernsheim) that became so pronounced towards the end of 1891 that an eruption was considered imminent and partial evacuation of the island took place. Another phase of unrest, involving strong local seismicity and marked ground deformation in the Matupit Island area, occurred between 1916 and 1919 (Fisher 1939). The next eruptive activity eventuated in 1937, 46 years after Hernsheim's report and 21 years after the start of the 1916-1919 unrest, but not before a brief period of intense unrest, involving strong and sustained seismicity and emergence of near-shore areas, that commenced $27 \mathrm{~h}$ before the onset of the eruptions at Vulcan and Tavurvur (Fisher 1939; Johnson and Threlfall 1985).

Seismic unrest within the Rabaul volcanic system primarily takes the form of volcano-tectonic (VT) earthquakes. VT earthquakes are high frequency events similar to tectonic earthquakes but are associated with a volcano and are therefore assumed to represent failure (fault movements) resulting from strain induced by volcanic processes (Lahr et al. 1994; Chouet et al. 1994). The VT earthquakes at Rabaul occur as discrete events and in clusters or swarms. The largest non-eruptive unrest events are termed "volcanic crises".

Volcanic crises at Rabaul are characterized by swarms of $\geq 150$ to thousands of VT earthquakes that occur within periods of a few hours (Mori et al. 1986, 1989). The threshold of 150 was based, somewhat arbitrarily, on the experience of the 1983-1985 "Crisis Period" (see below). The strongest earthquakes usually take place at or near the beginning of a crisis. The largest recorded event in any crisis was a $\mathrm{M}_{\mathrm{L}} 5.2$ 


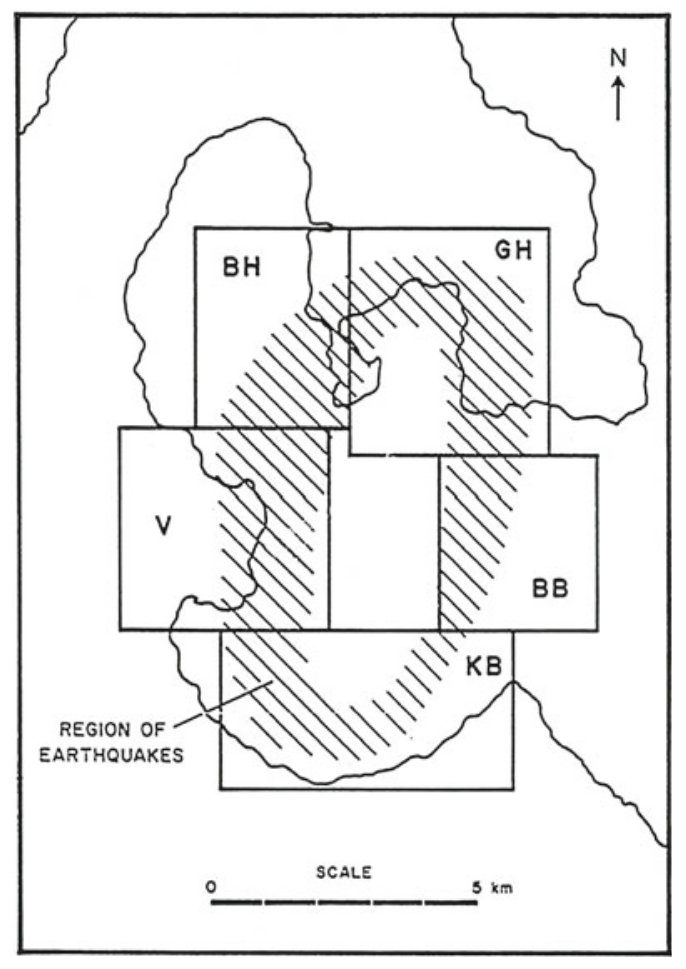

Fig. 2 Regions within the Rabaul Caldera seismic zone. $B H$ Beehives; $G H$ Greet Harbour; $V$ Vulcan; $B B$ Blanche Bay; $K B$ Karavia Bay

earthquake in October 1980. Seismicity of individual crises is usually confined to specific regions within the caldera seismic zone (Fig. 2), which is believed to include the fault system that bounds the youngest caldera (Mori et al. 1986, 1989). Caldera earthquakes take place at depths of $0-5 \mathrm{~km}$, although most events are shallow, 1$2 \mathrm{~km}$. In contrast, tectonic earthquakes of the northern Gazelle Peninsula region have a depth range of between about 10 and $280 \mathrm{~km}$ (Ripper et al. 1996; Ghasemi et al. 2016).

The ground deformation that takes place during volcanic crises is typically, but not always, inflationary, involving shallow-focussed uplift and tilting (McKee et al. 1984, 1989). The deformation occurs rapidly in direct association with the strongest earthquakes. Measured uplift at Matupit Island relative to a bench mark on the northwestern rim of the caldera (BM21, see
Fig. 1) has amounted to as much as $100 \mathrm{~mm}$ for an individual crisis. However, the greatest deformation is usually off-shore and is not readily measurable (Greene et al. 1986; McKee et al. 1989). The focus of the ground deformation is usually in the central part of the caldera, within the region bounded by the zone of caldera seismicity. However, the deformation may extend beyond the zone of seismicity.

\subsection{Volcanic Crises in the Period 1971-1985}

Following the eruptions of 1937-1943, volcanic unrest at Rabaul was at low levels until 1971. As far as is known, seismicity within the caldera from 1943 to 1971 was weak and consisted of occasional, isolated VT earthquakes of relatively small magnitude. Rates of ground deformation were also low as indicated by minimal elevation changes of a benchmark installed at Matupit Island in 1949 (Lauer, unpublished data). This benchmark is different to the one occupied in levelling surveys starting in 1973.

\section{1. $1971-1983$}

The relative calm of the period following the eruptions of 1937-1943 was disturbed in November 1971 by the first recorded swarm of caldera earthquakes (Cooke 1977). Compared with many of the seismic swarms and crises in the following two decades, the crisis of November 1971 was unremarkable. During the period November 1971-July 1983, there was a trend of increasing numbers of earthquakes in the seismic swarms and crises, from $<200$ in November 1971 to $\approx 1200$ in January 1982 (Fig. 3). Earthquake magnitudes also increased - the strongest earthquake was a $\mathrm{M}_{\mathrm{L}} 5.2$ event in the swarm of October 1980, and a slightly weaker event, $\mathrm{M}_{\mathrm{L}}$ 5.1, was recorded in the swarm of March 1982 (Table 1). $\mathrm{M}_{\mathrm{L}}$ determinations were made at RVO using an electronicallysimulatedWood-Anderson seismograph. For 


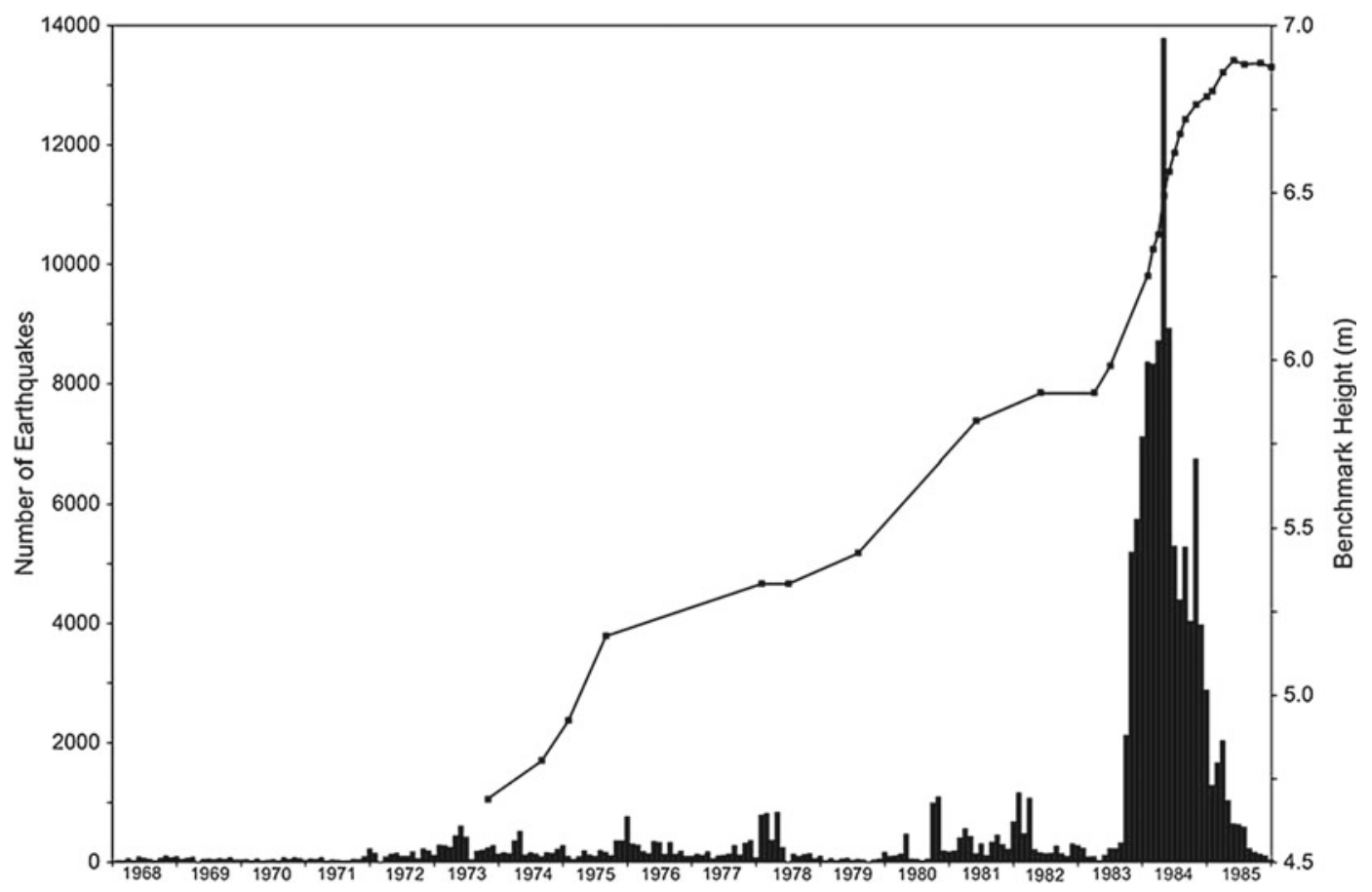

Fig. 3 Monthly caldera earthquake totals 1968-1985 and levelling results 1973-1985. Note increased frequency of levelling surveys starting from late-1983, during the early part of the Crisis Period

comparison the $\mathrm{M}_{\mathrm{L}} 5.2$ event of 28 October 1980 was assigned $\mathrm{M}_{\mathrm{L}} 5.0$ by Port Moresby Geophysical Observatory and $\mathrm{m}_{\mathrm{b}} 4.9$ by the National Earthquake Information Centre's PDE catalogue.

The spatial distribution of seismicity at Rabaul was discerned for the first time during this period due to improvements to both the local seismic network and to earthquake location techniques. The pattern of surface-projected seismicity was first represented as a "D"-shaped zone (Cooke 1977), and subsequently as two inward-facing arcuate zones, on the eastern and western sides of the caldera (Almond and McKee 1982). Later analysis suggested that the seismicity was related to a ring fault system (Mori and McKee 1987; Itikarai 2008) elongated north-south. The distribution of caldera seismicity for this period (1971-1983) is shown in Fig. 4.

Ground deformation monitoring during this period comprised levelling surveys, tiltmeter and dry tilt measurements, and strandline measurements. The results of these surveys indicated a generally steady rate of uplift of about
$110 \mathrm{~mm} /$ year in the central part of the caldera (Fig. 3). Gravity measurements reflected this uplift (McKee et al. 1989).

\section{1983-85: Crisis Period}

The period September 1983-July 1985 was one of sustained intensified activity at Rabaul. At the time it was generally considered that the increased activity could be the prelude to an eruption (McKee et al. 1984). The period was characterized by frequent major crises (many hundreds of VT earthquakes) and a large number of minor crises (a few hundred VT earthquakes), and therefore was termed the "Crisis Period" by Mori et al. (1986). This period was immediately heralded by a generally steady build-up in background seismicity from a "normal" level of 5-10 caldera earthquakes per day in August 1983 to 50-80 per day before the first crisis in September 1983 (Mori et al. 1986).

The first crisis of this period took place on 19 September 1983, in the eastern part of the caldera seismic zone (Blanche Bay, Fig. 2) and included 
Table 1 Seismic crises: October 1980-May 1985 (adapted from Mori et al. 1989)

\begin{tabular}{|c|c|c|c|}
\hline Date & Location & $\begin{array}{l}\text { No. Events } \\
\text { ( } 4 \text { or more stations) }\end{array}$ & $\begin{array}{l}\text { Largest } \\
\text { event }\left(M_{L}\right)\end{array}$ \\
\hline 28 Oct. 80 & Vulcan & $-* 1$ & 5.2 \\
\hline 4 Mar. 82 & Blanche Bay & —*1 & 5.1 \\
\hline 19 Sep. 83 & Blanche Bay & 210 & 4.2 \\
\hline 15 Oct. 83 & Greet Harbour/Beehives & 334 & 3.6 \\
\hline 28 Oct. 83 & Greet Harbour & 195 & 4.0 \\
\hline 26 Nov. 83 & Beehives/Vulcan & 212 & 2.9 \\
\hline 15 Jan. 84 & Greet Harbour/Beehives & 342 & 4.6 \\
\hline 13 Feb. 84 & Greet Habour & 164 & 2.6 \\
\hline 18 Feb. 84 & Karavia Bay/Vulcan & 212 & 4.3 \\
\hline 27 Feb. 84 & Blanche Bay & 159 & 3.0 \\
\hline 3 Mar. 84 & Blanche Bay & 484 & 5.1 \\
\hline 17 Mar. 84 & Vulcan & 219 & 2.1 \\
\hline 25 Mar. 84 & Beehives/Vulcan & 398 & 3.5 \\
\hline 11 Apr. 84 & Greet Harbour & 217 & 2.0 \\
\hline 13 Apr. 84 & Greet Harbour & 212 & 2.2 \\
\hline 20 Apr. 84 & Greet Harbour & 302 & 3.0 \\
\hline 21 Apr. 84 & Greet Harbour & $287 *^{2}$ & 3.7 \\
\hline 22 Apr. 84 & Greet Harbour & 485 & 4.8 \\
\hline 4 May 84 & Beehives/Vulcan & 168 & 3.5 \\
\hline 29 May 84 & Beehives/Vulcan & 323 & 3.6 \\
\hline 13 Jul. 84 & Vulcan & 151 & 3.5 \\
\hline 2 Aug. 84 & Beehives & 242 & 3.4 \\
\hline 17 Oct. 84 & Greet Harbour & $233^{* 2}$ & 4.9 \\
\hline 18 Oct. 84 & Blanche Bay & 158 & 3.8 \\
\hline 26 Oct. 84 & Vulcan & 209 & 3.2 \\
\hline 3 Mar. 85 & Beehives & 333 & 3.6 \\
\hline 10 May 85 & Vulcan & -*3 & 3.7 \\
\hline
\end{tabular}

Bold signifies stronger activity

$\mathrm{M}_{\mathrm{L}}$ determined at RVO using electronically-simulatedWood-Anderson seismograph

The event counts are for a $24 \mathrm{~h}$ period following the start of the crisis

${ }^{*}$ Event count not available

a $\mathrm{M}_{\mathrm{L}} 4.2$ earthquake. During the following few months the seismicity increased and by January 1984 the monthly total of caldera earthquakes had climbed to about 8300. In February and March 1984 the monthly total numbers of earthquakes remained about the same as in January. The crisis on 3 March 1984 was one of the strongest of the entire Crisis Period and included the largest earthquake, a $\mathrm{M}_{\mathrm{L}} 5.1$ event in the Greet Harbour area (Fig. 2). Re-occupation of the level line indicated that the southern tip of Matupit Island was rising at about $35 \mathrm{~mm} / \mathrm{month}$.

The activity reached a peak in April 1984 (Fig. 3). There were 5 crises in that month, all of which took place in the northeastern part of the caldera seismic zone (Greet Harbour, Fig. 2). 
Fig. 4 Caldera earthquake

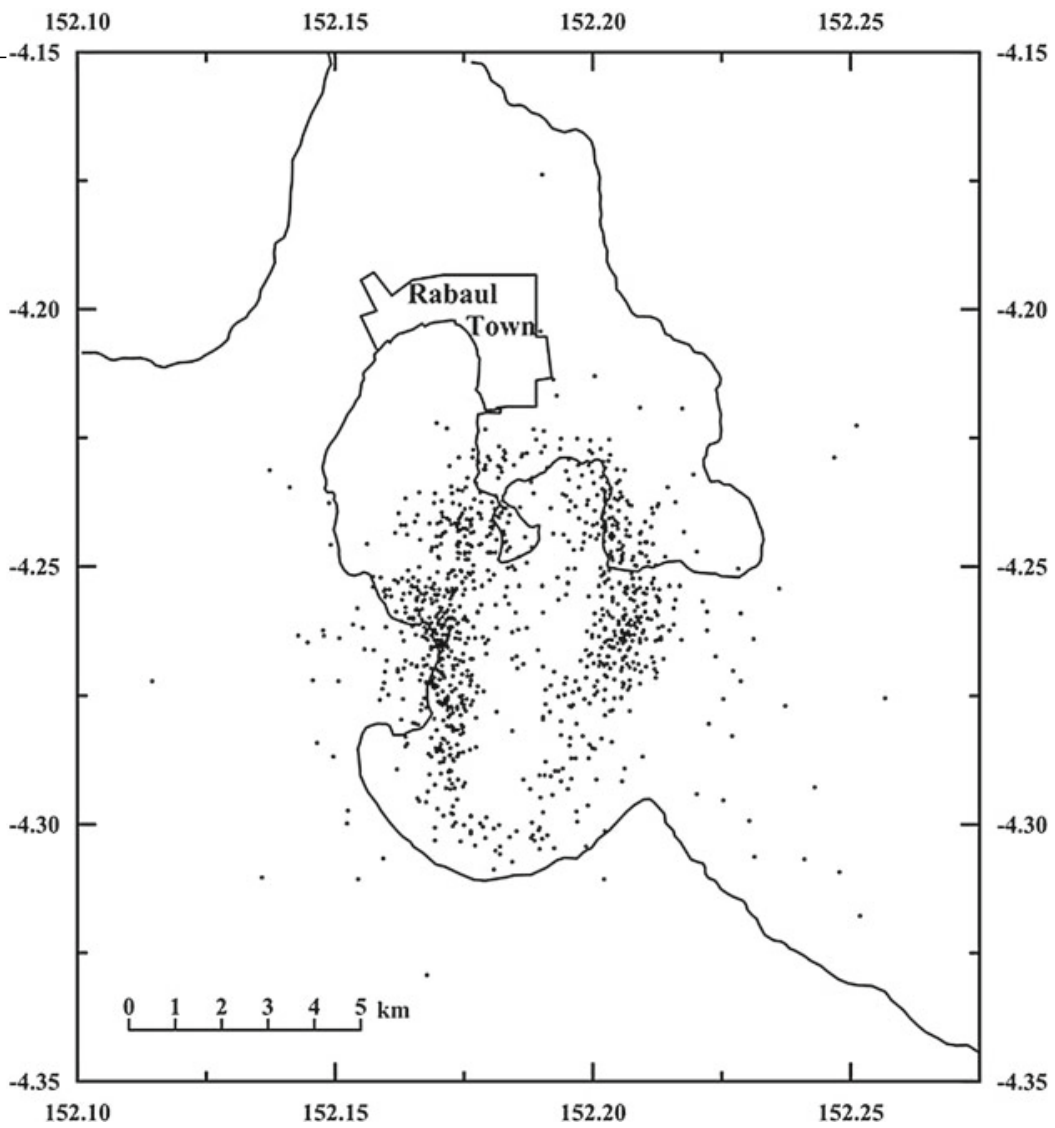

locations 01 November 1971--4.15

31 August 1983

Altogether, there were 25 major crises during

Crises took place on 3 consecutive days, 20th, 21st and 22nd of April, and the crisis on 22 April included a $\mathrm{M}_{\mathrm{L}} 4.8$ earthquake. The total number of earthquakes in April 1984 was about 14,000. Ground deformation was greatest in the central-northeastern part of the caldera. As much as $80 \mathrm{~mm}$ of uplift was recorded.

From May 1984 the activity declined. However, crises continued to take place occasionally, including one on 17 October 1984 during which the second strongest earthquake of the Crisis Period, a $\mathrm{M}_{\mathrm{L}} 4.9$ event, was recorded from the Greet Harbour area (Fig. 2). By the end of July 1985, seismic activity had returned to pre-Crisis levels. Also, there was a generally steady decline in the rate of uplift of the southern tip of Matupit Island, dropping to only a few mm/month by July 1985 . the period September 1983-May 1985 (Mori et al. 1986; Table 1). The intervals between the major crises ranged between 1 and 128 days. The seismicity shifted from one region to another of the caldera seismic zone during the Crisis Period but without showing any systematic patterns. The most active regions were those in the east to northeast (Blanche Bay, Greet Harbour; Fig. 2) and those in the west to northwest (Vulcan, Beehives; Fig. 2). Earthquake locations for the entire Crisis Period, September 1983-July 1985, are shown in Fig. 5. The greatest measured uplift for the 23 months of the Crisis Period was $767 \mathrm{~mm}$, at a benchmark at the southeastern end of Matupit Island (McKee et al. 1989). 
Fig. 5 Caldera earthquake

locations for the Crisis Period, -4.15 01 September 1983-31 July 1985

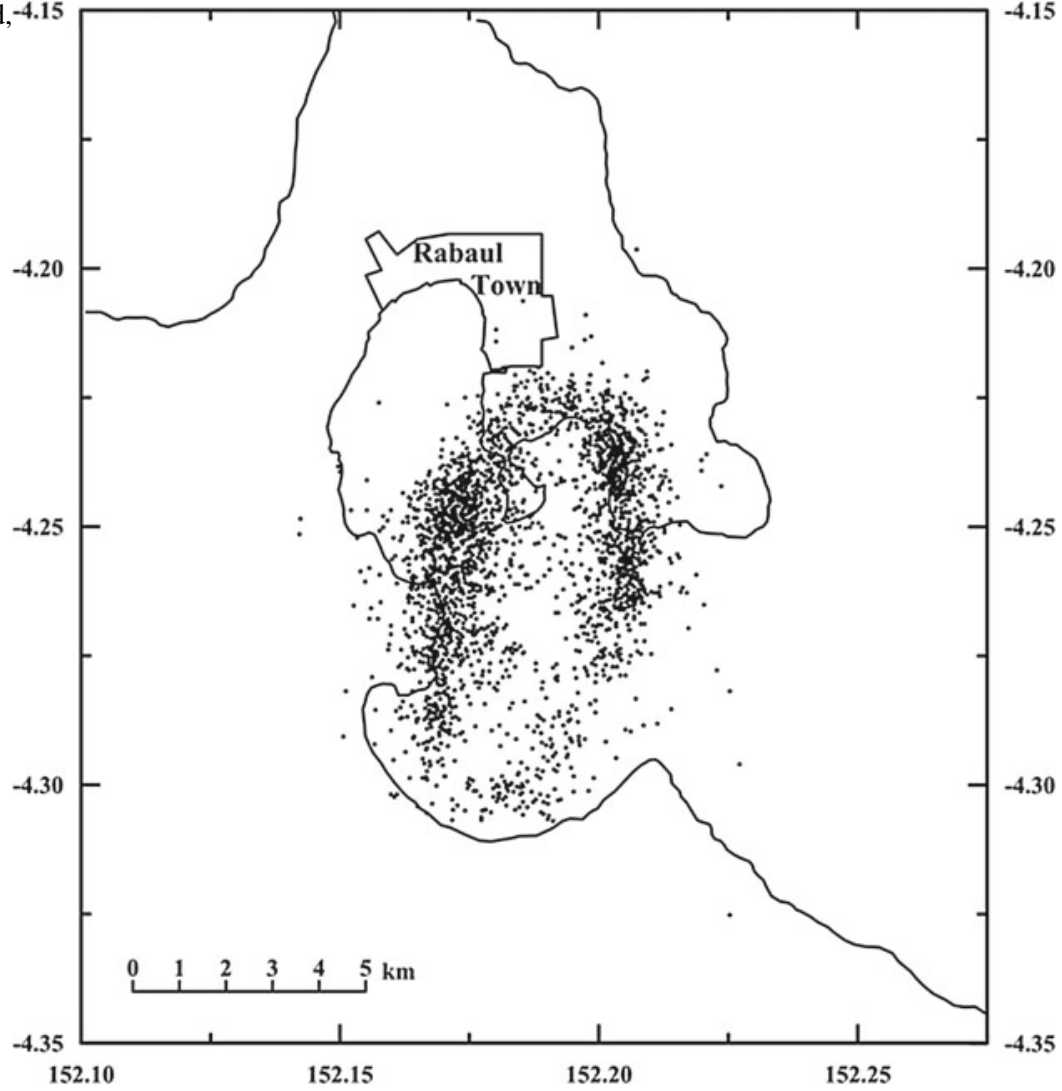

3 Impact of Precursory Activity (I): Volcano Monitoring, Contingency Planning and Public Awareness, 1983-1985

\subsection{Volcano Monitoring}

Prior to the 1983-85 Crisis Period the volcano monitoring system at Rabaul was unable to provide the necessary monitoring information promptly. Seismic data acquisition relied on manual timing of earthquakes from a microfilm recorder (Develocorder) and off-site data processing using the computing services of an accounting company. Thus, the determination of earthquake locations could take hours to days. Ground deformation monitoring relied mostly on levelling which was out-sourced to surveying staff from Department of Lands. Surveys were conducted at intervals ranging from 3 to 27 months.

Levelling surveys were more frequent from November 1983, at intervals of less than 1 month to about 3 months depending on events, and the surveys continued to be conducted by Lands Department staff. During a visit to Rabaul by Norman Banks of the United States Geological Survey (USGS) in December 1983, an electronic distance measuring (EDM) network was established and EDM monitoring commenced. In recognition of the need for a range of in-house ground deformation monitoring capabilities, a new position at RVO, Principal Surveyor, was created in 1985. The position was occupied from July 1985 and allowed RVO much greater control over the deformation monitoring program. With assistance from the Volcano Disaster Assistance Program (VDAP) of the USGS, telemetering electronic tiltmeters and tide gauges 
were installed at Rabaul in the wake of the Crisis Period.

On-site seismic data processing commenced in 1985 following the recruitment of new seismological staff equipped with personal computers. Earthquake location processing time was reduced to minutes, although the same microfilm recorder continued in service.

\subsection{Contingency Planning}

Concern about the growing volcanic unrest in the early 1980s prompted the development of a volcano contingency plan (VCP). Instigated by RVO, the first VCP for Rabaul was developed in early 1983 by provincial and national government authorities guided by UN-sponsored disaster planning expert, Brian Ward. The VCP was part of a Provincial Disaster Plan (PDP) for East New Britain, revised in 1985 by Captain Dwayne Hunt, RANR, and further revised in 1987 and in early 1994 by the Provincial Disaster Committee (PDC). The PDP set out the organizational structure of the PDC which was to include Sub-Committees for Rescue, Transport and Requisition, Evacuation and Welfare, and Command, Control and Communications. The composition and responsibilities of each of the Sub-Committees were specified in the PDP. Volcanic hazards assessments (McKee 1981; McKee et al. 1985) were the basis for definition of areas of danger and of relative safety (Fig. 6), and for the development of a 4-stage alert system:

Stage 1-Eruption in years to months. Normal preparedness.

Stage 2-Eruption within months. Prepare safe areas.

Stage 3-Eruption within weeks or days. Voluntary evacuation.

Stage 4-Eruption within days or hours. Evacuation.

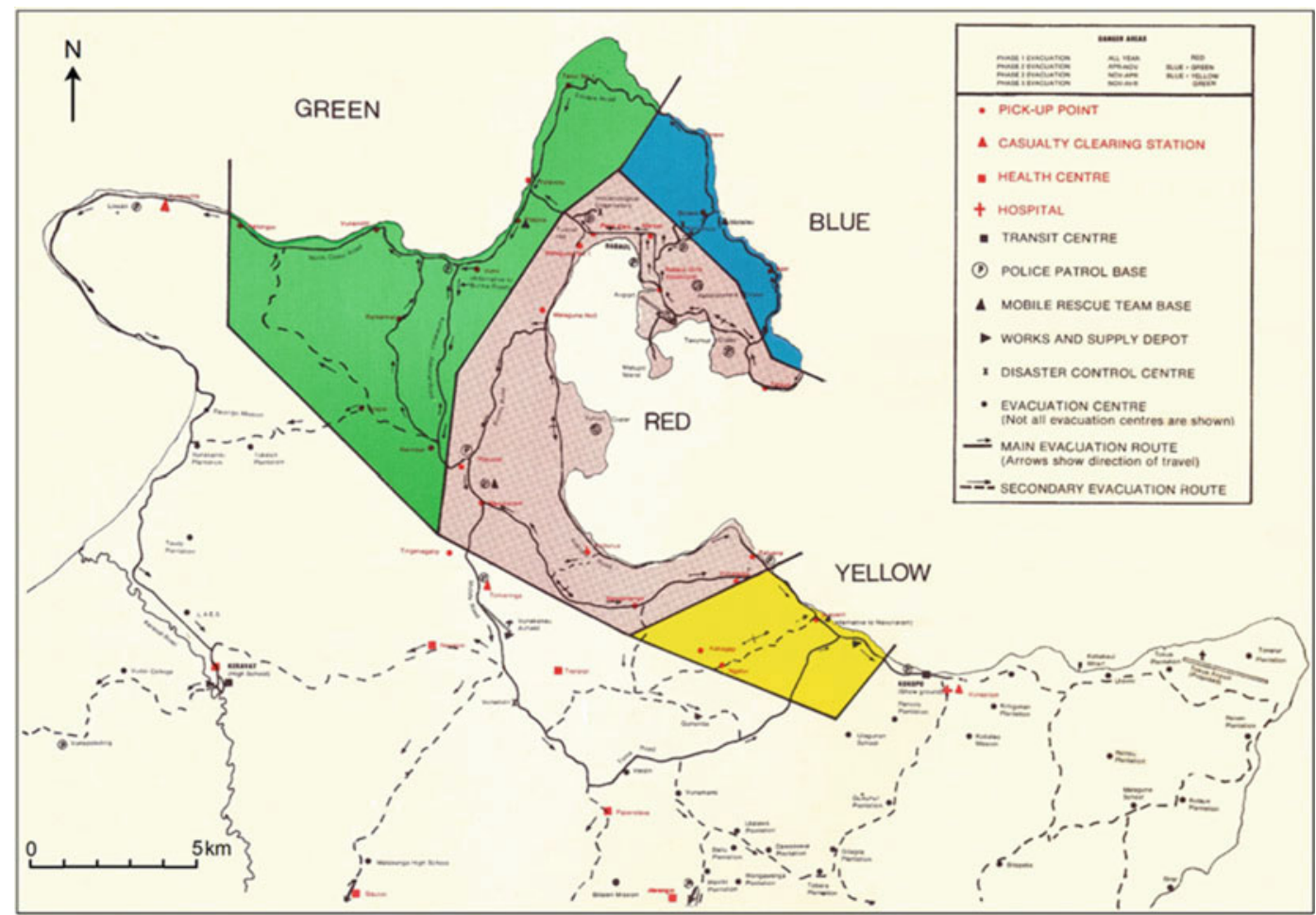

Fig. 6 Part of a poster showing hazard/danger zones and (relatively) safe areas; developed in 1983-1984 during the early part of the Crisis Period 
The main objective of the VCP was the re-location of about 60,000 people from the danger areas to areas of relative safety. Duplication of principal services, including alternative airport, hospital and communications, would support the planned re-location. In considerable detail, the plan defined the roles of National and Provincial Disaster Organizations and the actions of 12 Government Departments and other organizations, including: Civil Aviation, Education, Electricity, Health, Harbours and Marine, Police, Communications, Works and Supply and Red Cross. It is remarkable that the major churches were not involved initially. Several exercises of the contingency plan were conducted over the following decade. Typically, the exercises concentrated on communications between government agencies, and did not involve businesses or the general community of Rabaul.

Wide acceptance that Rabaul was heading towards an eruption prompted the development of eight new Acts of disaster-related legislation, which were passed by the National Parliament in the first two weeks of March 1984 (Davies 1995). The eight Acts were:

Disaster Management

Emergency General Powers

Emergency (Defence Force)

Emergency (Register Evacuees)

Emergency (Requisition)

Emergency (Requisition Compensation)

Emergency (Third Party)

Emergency (Workers Compensation)

These actions demonstrated that concerns about an impending eruption at Rabaul had reached to the highest levels of public service in PNG.

Significant progress was made as a result of the Crisis Period in preparing for duplication of services and infrastructure in safe areas, notably:

1. Re-opening of a former airstrip (Vunakanau, a WW2 airstrip).

2. Roads to and water supplies in the safe areas were improved.
3. A safe area headquarters command post was established (at Vunadidir).

4. Equipment and medical supplies were moved from Nonga Hospital, near Rabaul, to Vunapope Hospital, near Kokopo.

5. Construction began on a wharf near Kokopo.

6. Construction started on a new airport (Tokua, a WW2 airstrip).

It was considered that logistical arrangements for RVO staff and civil defence officials must be established well in advance of any volcanic emergency for the following:

- Food

- Water

- Accommodation

- Care of families

- Transport

- Security

- Emergency electricity supplies

- Rostering of staff

- Protection of property

- Emergency communications

\subsection{Establishment of Public Information Unit}

The marked increase in volcanic unrest in August-September 1983 led to the establishment of a Public Information Unit (PIU) to disseminate information about the unrest. The declaration of Stage 2 volcanic alert in late-October 1983 accentuated the public need for volcano information, but because of increased workloads in the volcano monitoring program volcanologists were unable to maintain the flow of information to the public. Some public distrust and disquiet developed with fears that important information was being withheld. These fears were fanned by irresponsible and over-dramatic stories in the press, some of which stressed the possibility of a catastrophic eruption.

The PIU was established by the East New Britain Provincial Government in early-February 
1984 (Davies 1995). At the suggestion of RVO the PDC requested the services of an Australian government geologist (Davies) to lead the unit. Davies had served in PNG for some years and was familiar with Rabaul, and was known to the RVO staff.

\subsection{Three Initiatives of PIU}

\section{Make all information available to the public}

As a first step towards confronting the problem of community distrust it was agreed among the volcanologists that all information should be made publicly available. Information released in the first week of March 1984 included plots showing the dramatic increases in seismic activity and in rates of ground deformation and explained the logic behind the declaration of a high-risk zone in the central-eastern part of the caldera, defined by ground deformation. A process was established for producing regular press releases: volcanologists presented information, PIU asked questions, and the resulting draft press release was vetted by volcanologists before release. The press releases were made available to all sections of media. Emphasis was placed on radio broadcasting as this was deemed the most effective method of reaching the largest audience.

\section{Town meetings and meetings with special interest groups}

Meetings involved:

Chamber of Commerce

School Principals

Staff and Students of the most-affected schools Church Officials

Insurance Company Representatives

Defence Force Officers

Harbours Board Management

The meetings provided valuable opportunities for the PIU to deliver information directly and, at the same time, to learn the concerns of the community.
The most-frequently-asked questions were:

- Would there be adequate warning?

- Might the situation jump from Stage 2 to Stage 4, without an intervening time in Stage 3 ?

- What was the best estimate of the size of the eruption?

Davies recalls that he was tempted to respond to questioners with reassuring words but realised that the success of his mission depended on retaining the trust of the people and for this reason it was necessary to be absolutely honest. He was pleased to find that the public response was not one of alarm but of calm, albeit concerned, acceptance. As had been observed by the celebrated volcanologist Gordon A. Macdonald: "People show a great ability to face dangerous situations with equanimity if they understand the situation. It is the unknown or the not understood danger that terrifies" (United Nations 1977).

\section{Local newspaper}

The national daily newspaper Post-Courier, printed in Port Moresby, proved to be an unsatisfactory conduit for conveying volcano information to the public. This problem was met face-on when local businessman, Joe Speccatori, established and produced Rabaul's own newspaper, the Rabaul Gourier (a pun based on the Melanesian Pidgin word "guria", meaning earthquake, and the name of the national newspaper). This provided up to date accurate information and was immensely popular during the worst of the crisis.

\section{Precursory Activity (II): 1985-1994}

\subsection{Fluctuating Activity: August 1985 to Mid September 1994}

For about 3 years following the 1983-85 Crisis Period the level of unrest at Rabaul was low. Seismicity was generally weak, interrupted occasionally by earthquake swarms. Subsidence 


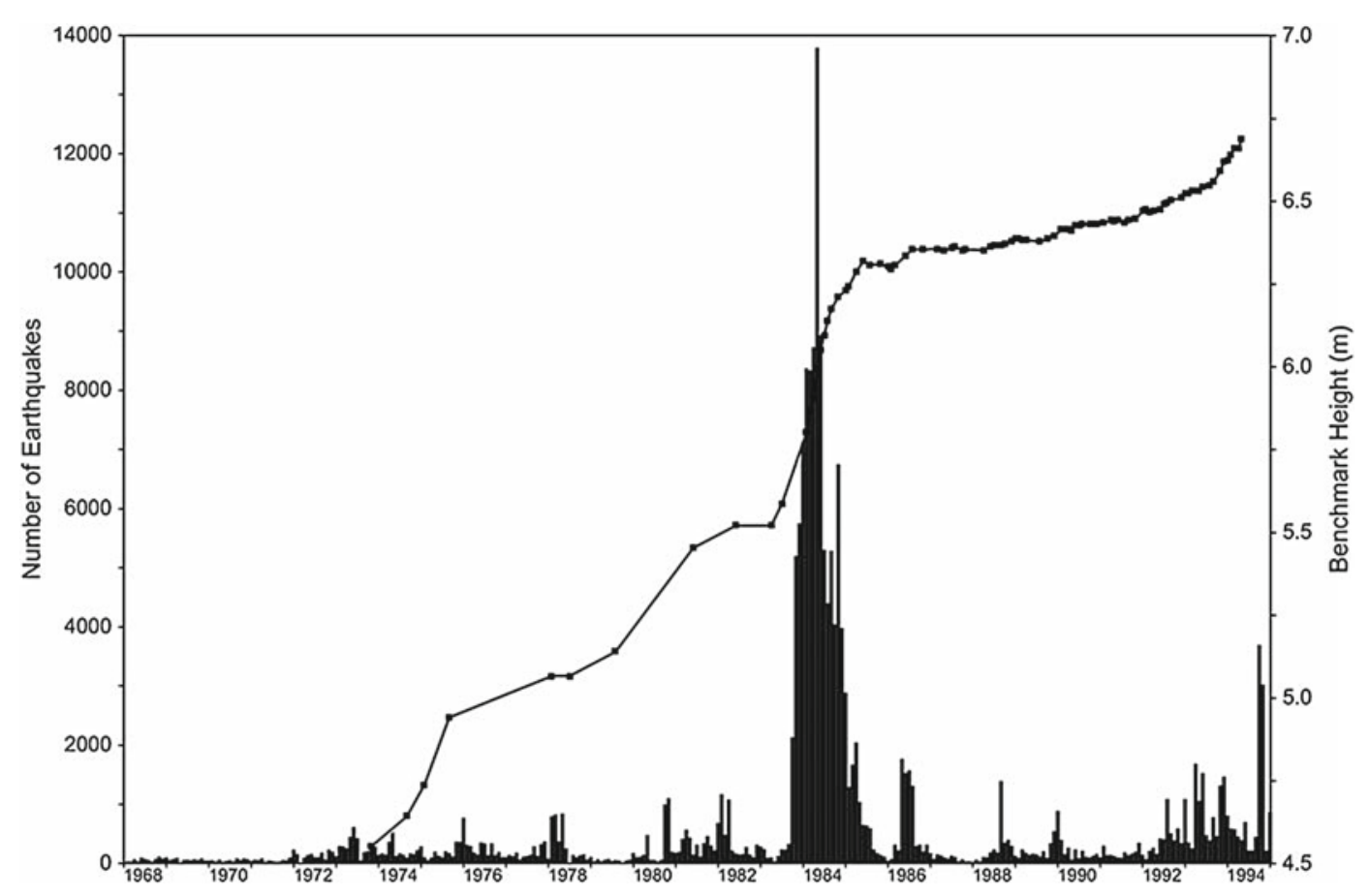

Fig. 7 Monthly caldera earthquake totals 1968-1994 and levelling results 1973-1994

was recorded near the margin of the youngest caldera during this interval, but the central part of the caldera floor continued to rise, albeit slowly (Fig. 7).

A $\mathrm{M}_{\mathrm{L}} 2.8$ caldera earthquake on 10 April 1988 and associated inflation of the caldera floor marked the beginning of a period of 4 years of moderate activity. Swarms of caldera earthquakes became more frequent with the strongest earthquake being a $\mathrm{M}_{\mathrm{L}} 3.5$ event in July 1990. Measured uplift at the Matupit Island benchmark during this interval amounted to about $150 \mathrm{~mm}$, giving a rate of about $40 \mathrm{~mm} / \mathrm{year}$. This rate is less than half the uplift rate of the pre-Crisis Period.

An unusual swarm of earthquakes that started on 2 May 1992 marked the beginning of a prolonged period of increased activity that continued until December 1993 (Fig. 7). The seismicity in early May 1992 took place about $2 \mathrm{~km}$ outside the northern part of the caldera seismic zone
(Fig. 8), under the eastern fringe of Rabaul Town, and consisted of more than 300 high frequency earthquakes, the largest of which was $\mathrm{M}_{\mathrm{L}} 4.2$ (Table 2). The locations of these earthquakes appeared to define a northeast-trending zone and led to the term "Northeast (NE) earthquakes" (Itikarai 2008). The significance of this seismicity remains uncertain, although a connection between NE earthquakes and phases of eruptive activity in the post-1994 period has been suggested (Itikarai 2008).

Caldera seismicity and rates of ground deformation began to increase after May 1992. A succession of caldera earthquake swarms was recorded, and one crisis took place, in May 1993 (Table 2). The crisis of 20 May 1993 was the first since the end of the 1983-85 Crisis Period, and included four $\mathrm{M}_{\mathrm{L}} 3.8$ earthquakes in the Greet Harbour area (Fig. 2). Data from the tide gauge network indicated uplift of 50-60 $\mathrm{mm}$ in the area of inferred maximum deformation, in the 
Fig. 8 Caldera earthquake locations for the period 01 August 1985-17 September 1994. Note the "northeast earthquake" zone near the eastern fringe of Rabaul Town

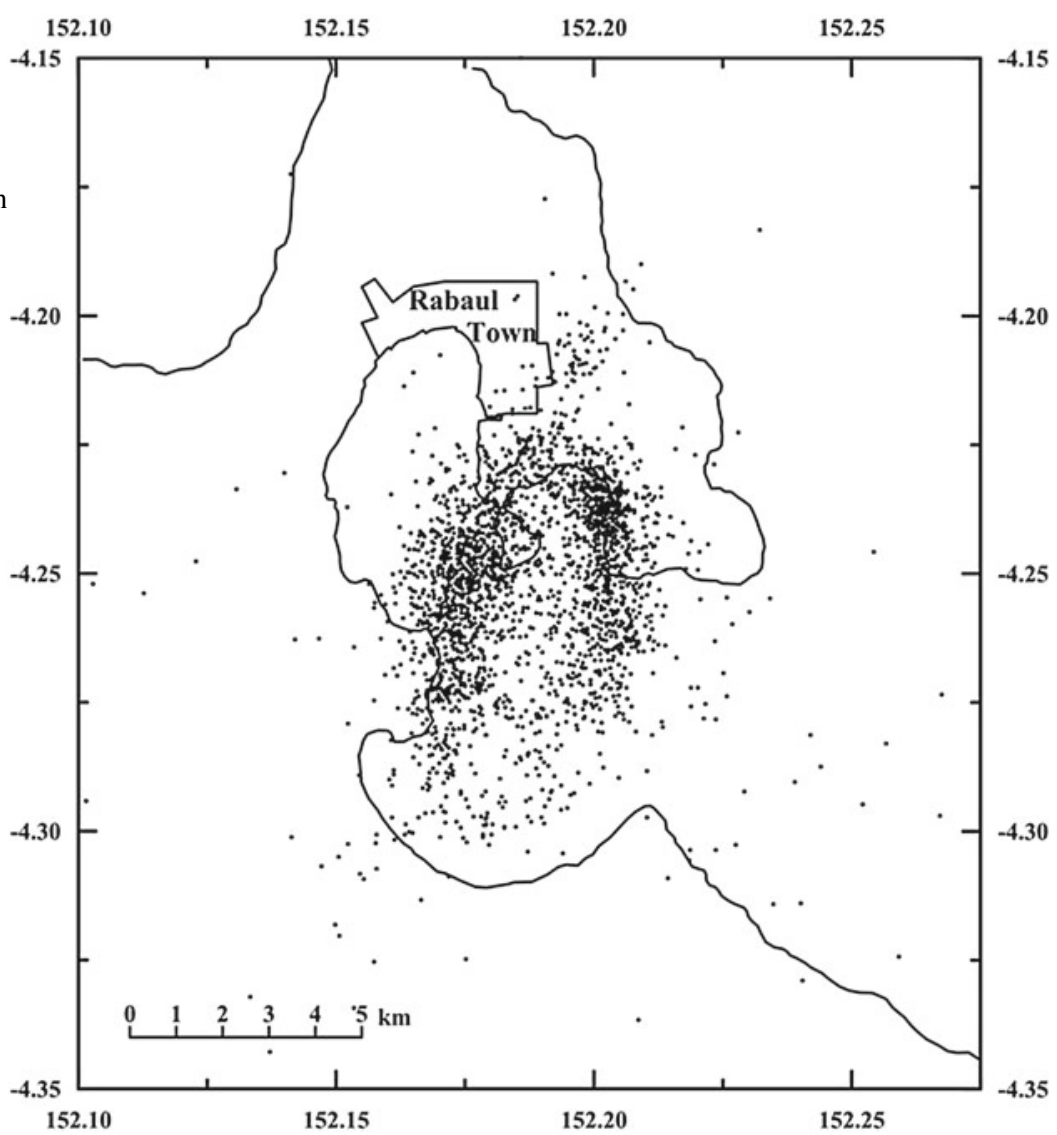

Table 2 Larger Rabaul earthquakes: 2 May 199218 September 1994 (adapted from Stewart and Itilkarai, unpublished data)

\begin{tabular}{l|l|l|l}
\hline Date & Time $(\mathrm{LT})$ & Location & Magnitude $\left(\mathrm{M}_{\mathrm{L}}\right)$ \\
\hline 02 May 92 & 0714 & Namanula & 4.2 \\
\hline 20 May 93 & 0643 & Greet Harbour & 3.8 \\
\hline 25 May 94 & 1043 & Beehives & 3.3 \\
\hline 25 May 94 & 1058 & Vulcan & 3.0 \\
\hline 18 Sep. 94 & $\mathbf{0 2 5 1}$ & Greet Harbour & $\mathbf{4 . 9}$ \\
\hline 18 Sep. 94 & $\mathbf{0 2 5 1}$ & Vulcan & $\mathbf{5 . 1}$ \\
\hline 18 Sep. 94 & 1203 & Vulcan & 4.3 \\
\hline 18 Sep. 94 & 1709 & Vulcan & 4.4 \\
\hline 18 Sep. 94 & 2042 & Vulcan & 4.4 \\
\hline 18 Sep. 94 & 2054 & Vulcan & 4.5 \\
\hline 18 Sep. 94 & 2307 & Vulcan & 4.1 \\
\hline 18 Sep. 94 & 2323 & Vulcan & 4.1 \\
\hline
\end{tabular}

Bold signifies stronger activity 
eastern-central part of the caldera. Tide gauge data confirmed that the deformation coincided with the seismic crisis.

Through most of 1994 until the day preceding the outbreak of eruptions a trend of generally declining seismicity was recorded (Fig. 7). There were many small earthquake swarms, but two stronger swarms took place on 25 May 1994 involving $\mathrm{M}_{\mathrm{L}} 3.3$ and 3.0 earthquakes in the Beehives and Vulcan areas respectively (Fig. 2, Table 2). Unusual "hybrid" earthquakes having high frequency onset and low frequency codas were recorded in the aftermath of the swarms of 25 May. The significance of those events was uncertain at that time, but it is now known that hybrid earthquakes of this type are common at other volcanoes with active hydrothermal systems and can be interpreted as episodes of fracture creating permeability that allows movement of hydrothermal fluids, or alternatively as episodes of fracture associated with propagation of magma-filled dykes (Faria and Fonseca 2014). Seismic swarms ceased after a relatively small swarm on 19 July 1994. In late August 1994, several hundred discrete earthquakes were recorded from near Tavurvur, and one hybrid earthquake was recorded. Earthquake locations for the period 01 August 1985-17 September 1994 are shown in Fig. 8.

Elevation changes within the caldera were moderate in the period January to mid-September 1994. A rise of about $100 \mathrm{~mm}$ was recorded at benchmarks at the southern end of Matupit Island during this period. The implied uplift rate is slightly greater than the average long-term rate of the pre-Crisis Period. However, in detail uplift rates declined at mid-year and there appeared to be slight subsidence in July. The decline in uplift rates may have coincided with the generation of the hybrid earthquakes, and may reflect depressurization of the hydrothermal system at Tavurvur.

Although the events of the period May 1992 to mid-September 1994 were reported to authorities, the significance of the NE earthquakes, the hybrid earthquakes, and the decline in uplift rates in mid-1994 was not appreciated at that time. In addition, maintenance and equipment problems led to a lack of telemetered data from tiltmeters and tide gauges by late 1993 which rendered the reliable interpretation of available ground deformation data more difficult. These deficiencies conspired to impede the generation of warning messages from RVO.

\subsection{The Ultimate Crisis of 18-19 September, 1994}

\section{Seismicity}

The 1994 eruptive outbreak at Rabaul was immediately preceded by the "Ultimate Crisis", $27 \mathrm{~h}$ of vigorous and fluctuating seismicity and remarkable ground deformation (Blong and McKee 1995). The timeframe and nature of these events in 1994 are eerily similar to the events that immediately preceded the 1937 eruptions (Fisher 1939). The seismicity of the Ultimate Crisis was initiated by two strong caldera earthquakes at 0251 on 18 September (Fig. 9, Table 2). The first earthquake was a $\mathrm{M}_{\mathrm{L}} 4.9$ event located near Tavurvur. The second earthquake was larger $\left(\mathrm{M}_{\mathrm{L}}\right.$ 5.1 ), and is believed to have originated from beneath the southern part of the Vulcan headland (Stewart and Itikarai, unpublished data). A small tsunami was generated by this earthquake and had greatest impact in the southern part of the caldera (Nishimura et al. 2005; Stewart and Itikarai, unpublished data).

The early part of this intense seismicity resembled a typical crisis. However, by early afternoon of the 18th the sustained nature of this activity caused concern at RVO and in some communities, notably those on the western side of the caldera and at Matupit Island. After about $14 \mathrm{~h}$ of seismic swarm activity, at about 1700 on the 18th, the seismicity intensified and it became clear to many people that conditions were unusual. Numerous felt earthquakes, many with magnitudes equal to or greater than $\mathrm{M}_{\mathrm{L}}$ 3.5, occurred between 1700 on the 18th and 0300 on the 19th. The felt seismicity tapered off towards dawn on the 19th.

Most of the earthquakes were located in the west-northwestern part of the caldera seismic 
Fig. 9 Caldera earthquake locations 18-19 September 1994

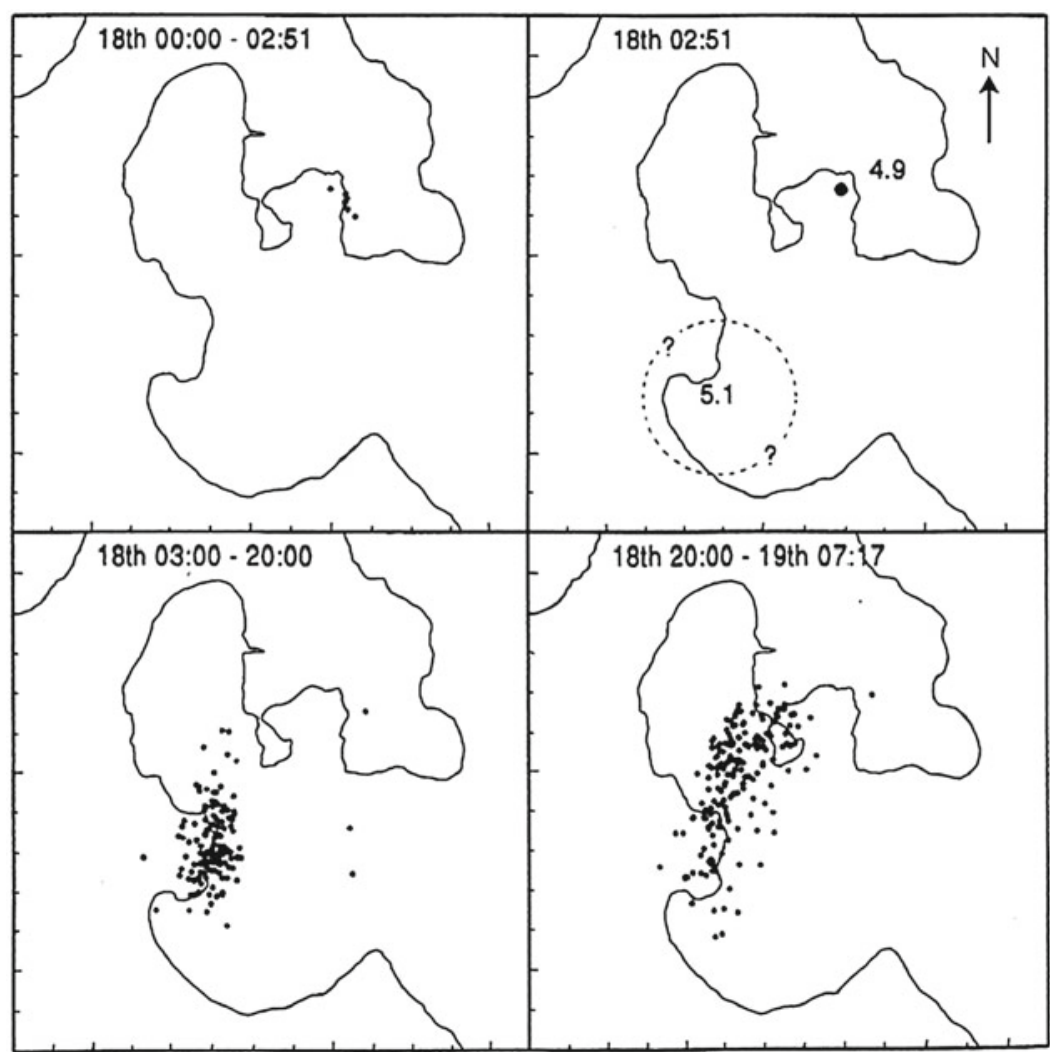

zone, i.e. the area between the Vulcan headland and Matupit Island, although the initial focus of the seismicity, following the main $\left(\mathrm{M}_{\mathrm{L}} 4.9\right.$ and 5.1) events, was under the Vulcan headland (Fig. 9).

\section{Ground Deformation}

The new telemetering electric tiltmeters and tide gauges that had been deployed as a result of the 1983-85 Crisis Period had become unoperational by 1994 because of maintenance and funding difficulties. Remarkable ground deformation started on the night of the 18th or early next morning, but was not detected until dawn, at about 0515 on the 19th. Uplift had occurred in the Vulcan area where a tide gauge pylon was almost fully exposed, indicating uplift of about $6 \mathrm{~m}$ (Fig. 10). The western and southern coasts of Matupit Island had also been raised and the southern shoreline had migrated about $70 \mathrm{~m}$ south. The estimated uplift of the western and southern parts of Matupit Island was about $2 \mathrm{~m}$. There was little or no evidence of elevation changes at Tavurvur. The overall pattern of the ground deformation appeared to be east-hingedup-tilting of the caldera block within the caldera seismic zone.

\subsection{Outbreak of Twin Eruptions: 19 September 1994}

New eruptions at Rabaul began just after 0600 on 19 September 1994, ending a repose period of about 51 years. Following the pattern of the previous two eruptive episodes, in 1878 (Brown 1878; Johnson et al. 1981) and 1937-43 (Fisher 1939; Johnson and Threlfall 1985), there were almost simultaneous outbursts on opposite sides of the caldera as Tavurvur and Vulcan began erupting at 0606 and 0717 , respectively. 


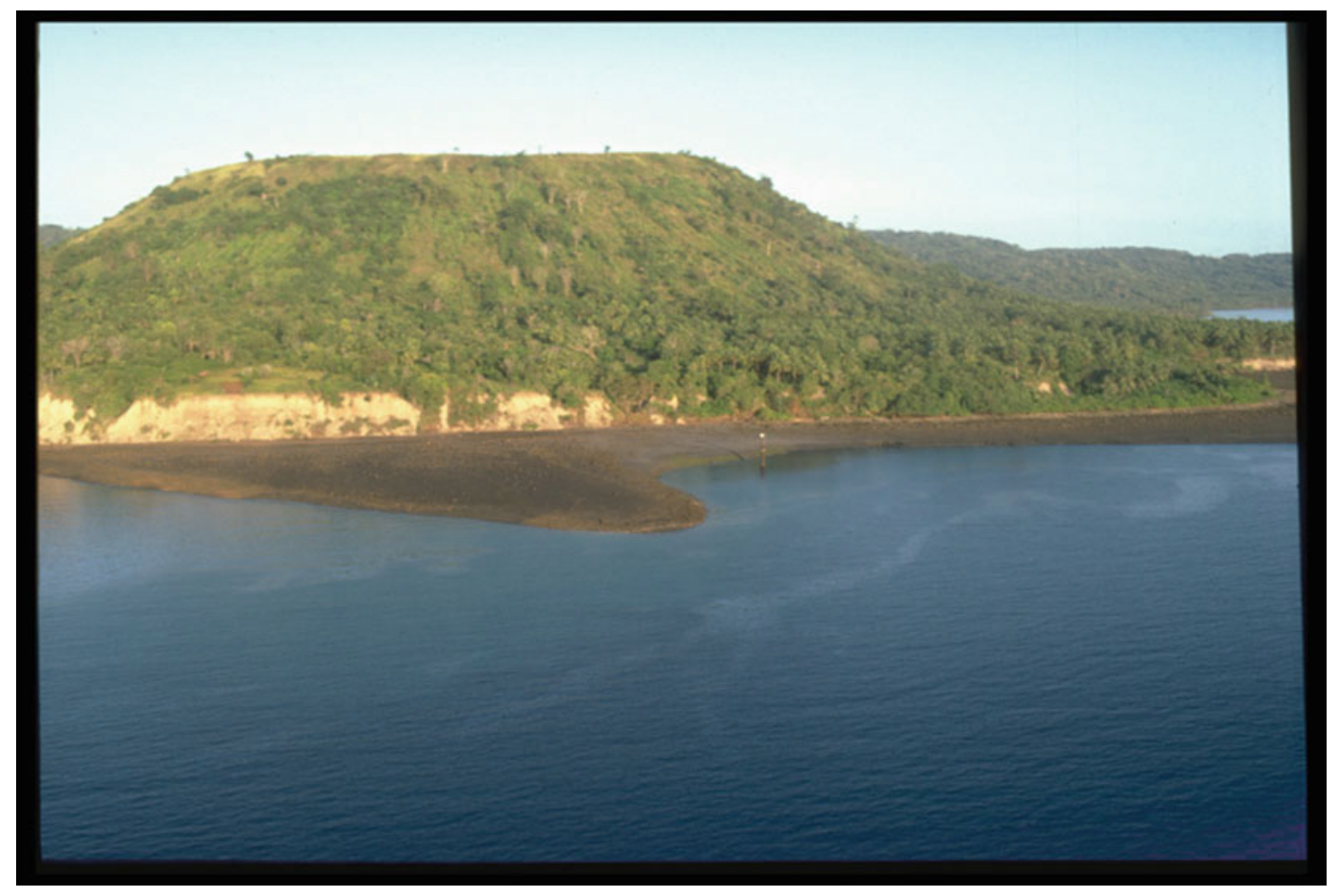

Fig. 10 Newly emerged sea floor at the eastern foot of Vulcan as seen at 6:15 a.m. on 19 September 1994. The near total exposure of the tide gauge pylon shown here in

\section{Responses to the Ultimate Crisis and Outbreak of Eruptions}

\subsection{Timeline of Events and Responses, 18-19 September 1994}

Responses to the physical (volcano-related) events in the immediate pre-eruption period were reported by Davies $(1994,1995)$ and are summarized in Table 3 . The responses include the actions by RVO, by the PDC and by communities resident within the caldera. The responses are discussed in the following sections.

\subsection{Response of Government Authorities}

As earthquake activity intensified during the afternoon of 18 September it became apparent that this the small embayment indicates about $6 \mathrm{~m}$ of uplift in this area. Photo courtesy of N. Lauer, formerly of RVO

activity was more than a typical crisis. A recommendation to raise the alert to Stage 2 was made by RVO to the PDC at about 6 p.m. on 18 September. The raising of the alert level was broadcast by local radio and spread by word of mouth.

An exodus of people from villages near Vulcan started in late afternoon. By dusk people started to evacuate Matupit Island and the southern town area. Those who did not have transport were advised to congregate at the Queen Elizabeth Park (QEP) sports field (Fig. 1) in the Rabaul Town area (as stipulated in the VCP).

At around 11 p.m. the PDC began the evacuation of about 5000 people who had gathered at QEP. All available transport worked through the night until the early hours of the next day to ferry people out of the caldera.

At about midnight RVO advised the PDC that "Rabaul Volcano was on an irreversible course towards an eruption" and that a recommendation for declaration of a Stage 3 Alert was imminent. By 2 a.m. on 19 September that recommendation 
Table 3 Events and responses timeline, 18-19 September 1994

\begin{tabular}{|c|c|c|c|c|}
\hline Time & Event & RVO & PDC (NDES) & Communities \\
\hline \multicolumn{5}{|l|}{18 Sept } \\
\hline 0251 & $\begin{array}{l}\mathrm{M}_{\mathrm{L}} 4.9,5.1 \\
\text { earthquakes, tsunami }\end{array}$ & $\begin{array}{l}\text { Processed and } \\
\text { analysed eq. data }\end{array}$ & & $\begin{array}{l}\text { Most people awakened } \\
\text { by eq. shaking }\end{array}$ \\
\hline 0800-1200 & $\begin{array}{l}\text { Sustained } \\
\text { moderate-strong } \\
\text { seismicity }\end{array}$ & $\begin{array}{l}\text { Processed eq. data } \\
\text { Investigated eq., } \\
\text { tsunami impact }\end{array}$ & & \\
\hline $1200-1700$ & $\begin{array}{l}\text { Sustained strong } \\
\text { seismicity }\end{array}$ & Processed eq. data & & $\begin{array}{l}\text { Growing concern with } \\
\text { continuing seismicity }\end{array}$ \\
\hline 1700 & Seismicity intensifies & Processed eq. data & & $\begin{array}{l}\text { Mobilization of } \\
\text { communities on } \mathrm{W} \text { side } \\
\text { of caldera (Tavana, } \\
\text { Valaur) }\end{array}$ \\
\hline 1800 & $\begin{array}{l}\text { Sustained intensified } \\
\text { seismicity }\end{array}$ & $\begin{array}{l}\text { Communication to } \\
\text { PDC to increase alert } \\
\text { to Stage } 2\end{array}$ & $\begin{array}{l}\text { Stage } 2 \text { declared, broadcast } \\
\text { on local radio }\end{array}$ & $\begin{array}{l}\text { Evacuation of Matupit } \\
\text { Is., southern part of } \\
\text { Rabaul Town } \\
\text { Assembly of residents } \\
\text { at QEP }\end{array}$ \\
\hline 2300 & $"$ & & $\begin{array}{l}\text { Directed evacuation of people } \\
\text { gathered at QEP }\end{array}$ & $\begin{array}{l}\text { Evacuation of most } \\
\text { communities resident } \\
\text { within caldera }\end{array}$ \\
\hline 2400 & $"$ & $\begin{array}{l}\text { Communication to } \\
\text { PDC that eruption } \\
\text { anticipated }\end{array}$ & $\begin{array}{l}\text { Conveyed message that eruption } \\
\text { anticipated }\end{array}$ & Continued evacuation \\
\hline \multicolumn{5}{|l|}{$19 \mathrm{Sept}$} \\
\hline 0200 & $"$ & $\begin{array}{l}\text { Communication to } \\
\text { PDC and NDES to } \\
\text { increase alert to Stage } \\
3 \\
\text { Arranged for aerial } \\
\text { inspection at } 0600\end{array}$ & $\begin{array}{l}\text { Continued to convey message that } \\
\text { eruption anticipated }\end{array}$ & $\begin{array}{l}\text { Evacuation of all } \\
\text { communities resident } \\
\text { within caldera } \\
\text { completed }\end{array}$ \\
\hline 0300 & & & $\begin{array}{l}\text { Stage } 3 \text { declared (NDES), broadcast } \\
\text { on Radio Australia }\end{array}$ & \\
\hline 0515 & $\begin{array}{l}\text { Emergence of seafloor } \\
\text { around Vulcan and } \\
\text { Matupit Is first } \\
\text { observed }\end{array}$ & $\begin{array}{l}\text { Notified PDC that } \\
\text { eruption imminent }\end{array}$ & & \\
\hline 0606 & $\begin{array}{l}\text { Outbreak of eruption at } \\
\text { Tavurvur }\end{array}$ & $\begin{array}{l}\text { Observed outbreak } \\
\text { during aerial } \\
\text { inspection }\end{array}$ & & \\
\hline 0700 & & & $\begin{array}{l}\text { Stages } 3 \text { and } 4 \text { declared locally, and } \\
\text { request for declaration of State of } \\
\text { Emergency (subsequently declared) }\end{array}$ & \\
\hline 0717 & $\begin{array}{l}\text { Outbreak of eruption at } \\
\text { Vulcan }\end{array}$ & $\begin{array}{l}\text { Observed outbreak } \\
\text { from RVO }\end{array}$ & & \\
\hline
\end{tabular}

had been faxed from RVO to the PDC and to the National Disaster and Emergency Services (NDES) headquarters in Port Moresby. The Director of NDES (Leith Anderson) subsequently notified the Port Moresby-based representative of
Radio Australia, Sean Dorney, of this development which was then broadcast (at about 3 a.m.).

Following the advice from RVO that an eruption was inevitable members of the PDC advised clubs, hotels, boarding schools and 
others that people should move out from the caldera. This was done by phone calls and by Police and Red Cross officials moving through the streets advising evacuation.

The local radio station remained on air until 12:30 a.m. on 19 September, and resumed broadcasting at 5:30 a.m. until the eruption began. Through this time the station continued to broadcast the message that Rabaul was on Stage 2 Alert and that people should remain in their homes until further notice. This anomaly arose because the PDC had decided to delay declaring Stage 3 Alert until first light. The PDC reasoned that the evacuation was proceeding smoothly during the night and it was felt that announcement of a heightened state of alert might cause panic and unnecessary havoc on the roads.

Rabaul Town and all villages within the caldera were evacuated by the early hours of 19 September. The evacuation was conducted smoothly and the entire process was completed within $12 \mathrm{~h}$. However, some residents of Talwat village, just outside the eastern margin of the caldera, did not join the mass exodus from Rabaul on 18-19 September. Likewise, most residents of villages east and northeast of Rabaul Town (Baii, Nodup, Matalau, Korere etc., see Fig. 1) did not evacuate at this time.

At 7 a.m. on 19 September the PDC declared simultaneously Stage 3 and Stage 4 Alerts, and requested the declaration of a State of Emergency. By that time Tavurvur's eruption had already started and within about $1.5 \mathrm{~h}$ a dense emission plume had engulfed Rabaul Town (Fig. 11). The State of Emergency was approved by the Prime Minister and declared by the Director NDES (Leith Anderson). Anderson was appointed Controller of the Emergency and the Chairman of PDC, Ellison Kaivovo, was appointed Deputy Controller.

A command post for emergency operations was established at Ralum, near Kokopo, on the second morning of the eruptions. The original plan for command post operations to be headquartered at Vunadidir was abandoned when that area received tephra fall from the Vulcan

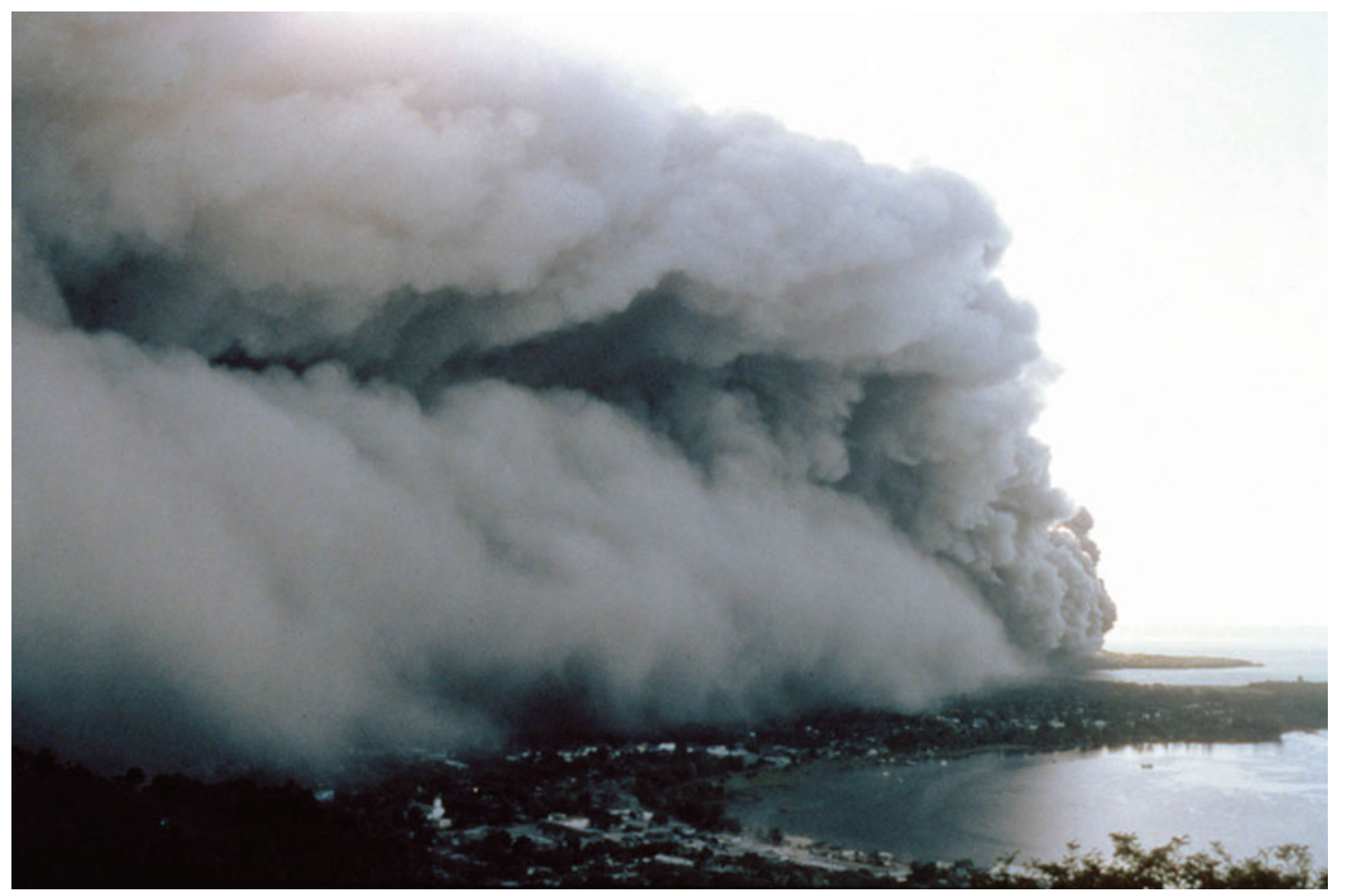

Fig. 11 Tavurvur emission plume engulfing Rabaul Town at about 7.25 a.m. on 19 September 1994, as viewed from RVO. Photo courtesy of N. Lauer, formerly of RVO 
emissions. The Ralum location for the command post probably was a better option, being more conveniently-located for a range of services.

Telephone communications in the region were seriously disrupted during the first few days of the eruption. Lightning strikes in the mid-late afternoon of 19 September damaged the telephone system at RVO. The loss of the Rabaul Telephone Exchange on the morning of 20 September, due to collapse of the roof of the building under a heavy load of wet volcanic ash, caused a temporary break in communications in the Rabaul area. Earlier on the same day operation of the Kokopo Telephone Exchange was halted by an electrical power outage.
Loss of volcano-monitoring capability at RVO began on the first day of the eruptions. Seismic monitoring equipment and telemetry links were damaged by heavy falls of tephra and by lightning strikes. On the morning of 20 September heavy rainfall overwhelmed drainage from the roof of the main RVO building and incursion of muddy water into the roof space resulted in water damage inside the building and distraction from eruption monitoring activities.

The PIU played an important part in conveying volcano-related information from RVO to the PDC, to the displaced people in care centres (Fig. 12) and to the news media. Led by $\mathrm{H}$. Davies, who travelled from Port Moresby to
Fig. 12 Locations of care centres for evacuees
CARE CENTRES

(Created during Volcano Disaster)

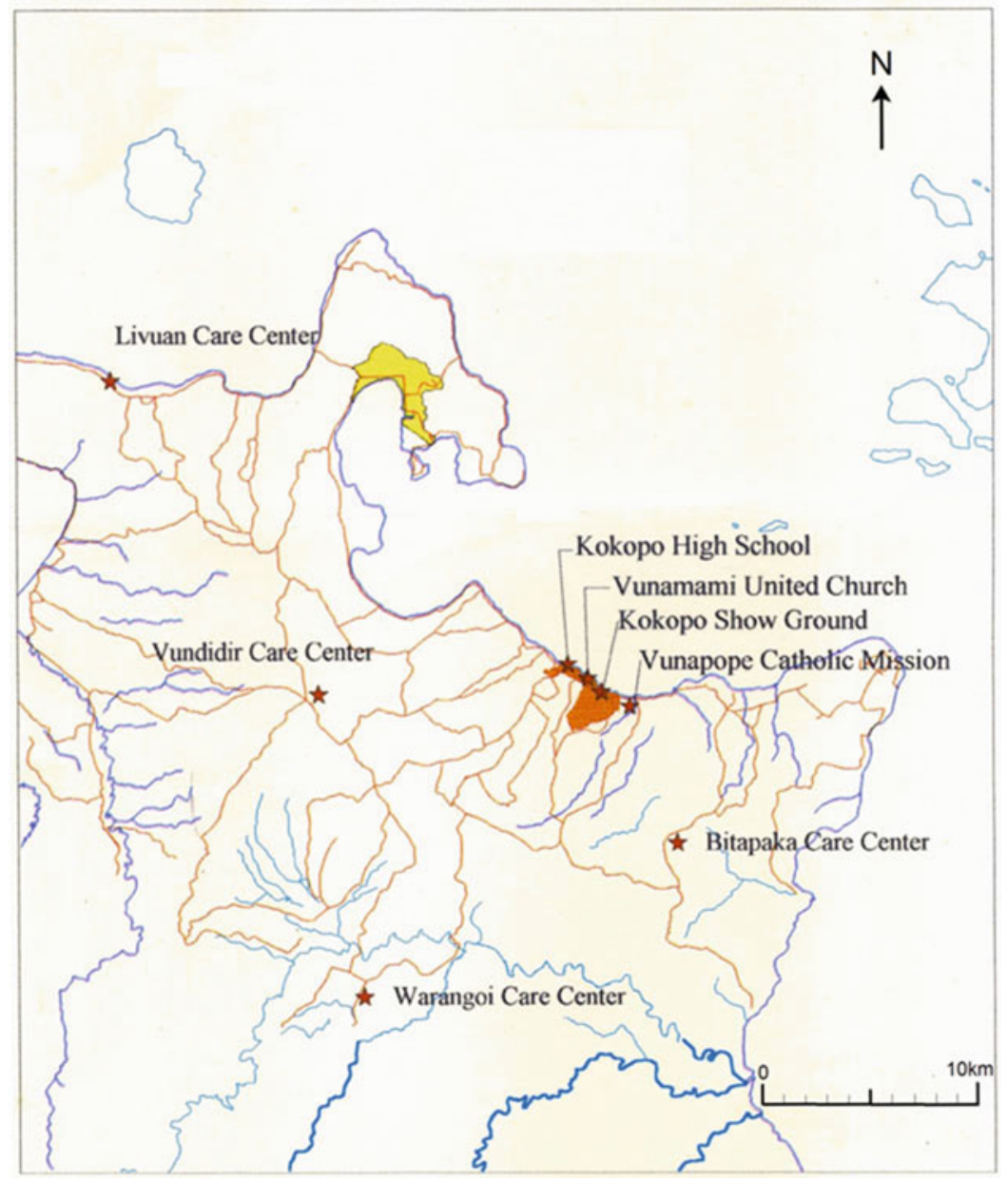


Kokopo on 23 September, the PIU was assisted by local resident geologist David Lindley (Lindley 1995) and occasionally by volcanologists from RVO.

\subsection{Community Response}

The responses of the traditional communities to the volcanic events of 1994 were shaped by experience and knowledge. Memories and stories of the events preceding the 1937 eruptions and of the approximately 500 fatalities near Vulcan during that eruption are still strong within these communities. The 1937 eruptions were preceded by $27 \mathrm{~h}$ of intense local earthquake activity, accompanied by dramatic late-stage emergence of the seafloor in the Vulcan and Matupit Island areas (Fisher 1939; Johnson and Threlfall 1985). The timeframe and the nature of the geological activity on 18-19 September 1994 were very similar to the events of 1937. However, the general community response to the pre-eruption geological activity in 1994 probably was based only on the earthquake activity, as also suggested by Neumann (1996) from anthropological research, as the massive uplift in the Vulcan and Matupit Island areas took place at night and was not observed until first light on 19 September. By that time nearly all of the people normally resident within and near the caldera had evacuated.

Another element of the general community response in 1994 was the conditioning through 23 years of precursory activity. The attention of the community to the volcanic threat became highly focussed during the mid-1980s Crisis Period (McKee et al. 1985). Information provided by the PIU and other agencies prompted individuals, family units and larger groups to make their own volcano contingency plans in the light of the broader official volcano contingency plan. However, the long delay (10 years) between the peak of the Crisis Period and outbreak of eruptions may have caused some complacency within the community about the lingering volcanic threat. Additionally, changes to the migrant and expatriate communities would have weakened the focus on preparedness for eruptive activity.
It was reported by Neumann (1996) that a group of people from Valaur Village (near Tavana village) visited RVO on the morning of 18 September anxious about the seismic activity. The village group was allegedly told by RVO staff "not to worry" about the earthquakes. The details of that exchange cannot be verified, however at that early stage of the Ultimate Crisis a judgement on the significance of the seismicity would have been difficult to make. Similar activity had been recorded previously (see Table 1), notably September-October 1980 (including an $\mathrm{M}_{\mathrm{L}} 5.2$ earthquake), March 1982 (including an $\mathrm{M}_{\mathrm{L}} 5.1$ earthquake), March 1984 (including an $\mathrm{M}_{\mathrm{L}} 5.1$ earthquake), April 1984 (three consecutive days of crisis activity including an $\mathrm{M}_{\mathrm{L}} 4.8$ earthquake) and October 1984 (including an $\mathrm{M}_{\mathrm{L}} 4.9$ earthquake).

Differences between the activity of 18-19 September 1994 and crises of the 1980s became clearer through the afternoon of the 18th when felt earthquake activity continued and appeared to be strengthening. A series of magnitude 4 earthquakes from the Vulcan area began at about midday on the 18th, with more frequent such earthquakes occurring after about 2000 LT (Table 2).

The rapid evacuation of areas near Vulcan in the afternoon of the 18th appears to have been a reasoned and conscious response to a situation perceived to be different to those experienced during the crises of the 1980s, and bearing similarities to the earthquake activity prior to the 1937 eruptions as remembered by village elders. A similar response may have occurred at Matupit Island. As the spontaneous evacuation gathered pace some people may have been influenced by the actions of those around them to join the exodus. Such behaviour would have been further fuelled by the sight and sound of aircraft taking off from Rabaul airport (Lakunai; Fig. 1) during the hours of darkness on 18-19 September. Those actions may have provided powerful communications to observers, as a case of "actions speaking louder than words". This phenomenon was evident from interviews with survivors of the 2011 Tohoku tsunami (Ando et al. 2013) which showed that many people 
began to evacuate coastal towns before the tsunami arrived, simply because they saw other people evacuating.

There was a sharp contrast between the actions and reactions of village communities east and northeast of Rabaul Town and those resident within the caldera. The village communities east and northeast of Rabaul Town may have heeded the local radio broadcast messages to stay put. Also, the lower intensity of felt earthquake activity in these areas may have been a factor in prompting these communities to not evacuate during the afternoon or night of the 18th. Evacuation of these communities and the remaining residents of Talwat took place on 20-21 September, assisted by a number of ships (Fig. 13).

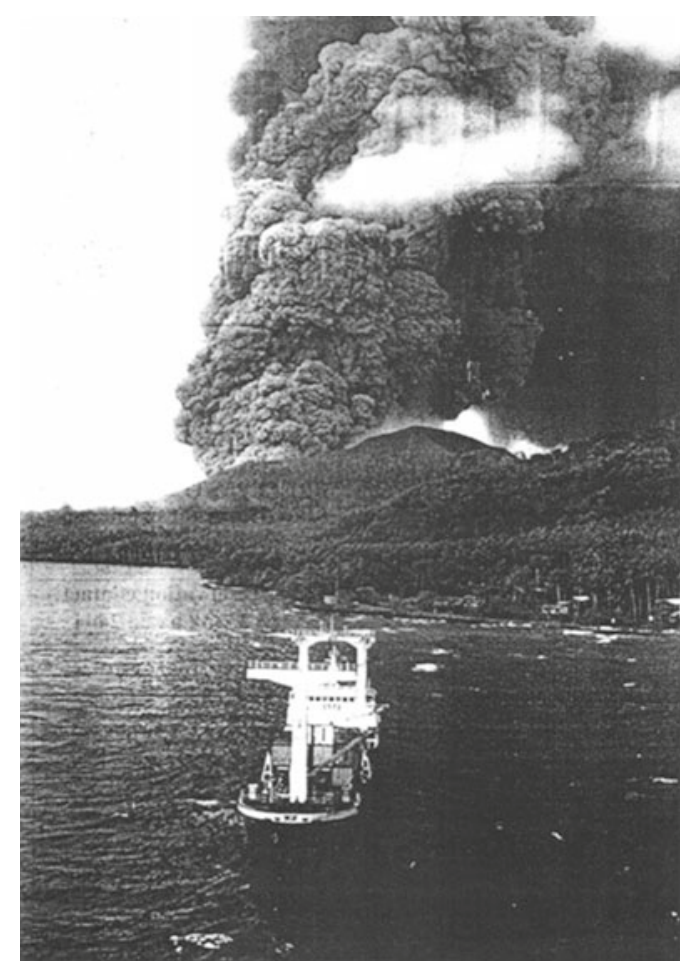

Fig. 13 Evacuation of some residents of Talwat village on 20 September 1994, assisted by MV Madang Coast. A dense, convoluting emission plume rises from Tavurvur in the background. Further in the background is the stratovolcano Kabiu. Photo courtesy of South Pacific Post Courier
One very disturbing response to the Ultimate Crisis and outbreak of eruptions in 1994 was looting. The looting started in Rabaul Town on the night of 18 September as the evacuation proceeded. During the early part of the eruption looting became widespread as residents of villages outside of the caldera took advantage of unoccupied houses and the lack of strong action on the part of police to secure the town. Check points were established at the main roads but there was little effort to stop people from going into the town area or to stop trucks laden with looted goods from leaving.

\subsection{Outcomes}

The eruption at Vulcan was a powerful, short-lived plinian event (Fig. 14), producing about $260 \times 10^{6} \mathrm{~m}^{3}$ of tephra mostly in the first few days of activity, and concluding on 2 October 1994 (Blong and McKee 1995). Tavurvur's eruption was less powerful (vulcanian) but persistent, continuing for years. The output rate at Tavurvur peaked during the first days of activity when about $40 \times 10^{6} \mathrm{~m}^{3}$ of tephra was erupted.

The death toll from the 1994 eruptions was relatively small, officially 10 . The 10 eruption-related deaths comprised 3 due to tephra fall and associated asphyxia, 1 due to lightning, 3 from road trauma, 2 from desertion (ill and incapacitated persons), and 1 from drowning in a flash flood 6 weeks after the start of the eruptions (Dent et al. 1995). This small death toll is in stark contrast to 1937 when as many as 500 people perished, mostly caught in pyroclastic flows and heavy tephra fall in the Vulcan area (Fisher 1939). As mentioned, the events of 1937 and the recognition of the on-going volcanic threat led to the establishment of RVO in 1940. The instrumental volcano surveillance that ensued helped to better inform the residents of the Rabaul area of the local volcanic threat and led to the detailed planning that helped to manage the long precursory period and the inevitable eruptions in 1994. 
Fig. 14 Vulcan's eruption column and plume as seen from the Space Shuttle at about 7 a.m. on 20 September 1994. At this time the eruption column was rising to at least $18 \mathrm{~km}$ (astronaut's estimate) and feeding a broad, wedge-shaped emission plume the axis of which was oriented southwest. In this view from the east-northeast, the eastern coast of New Ireland can be seen beneath the extensive white cloud cover in the foreground, and part of the eastern coast of the Gazelle Peninsula is visible in the left middleground. Photo courtesy of NASA

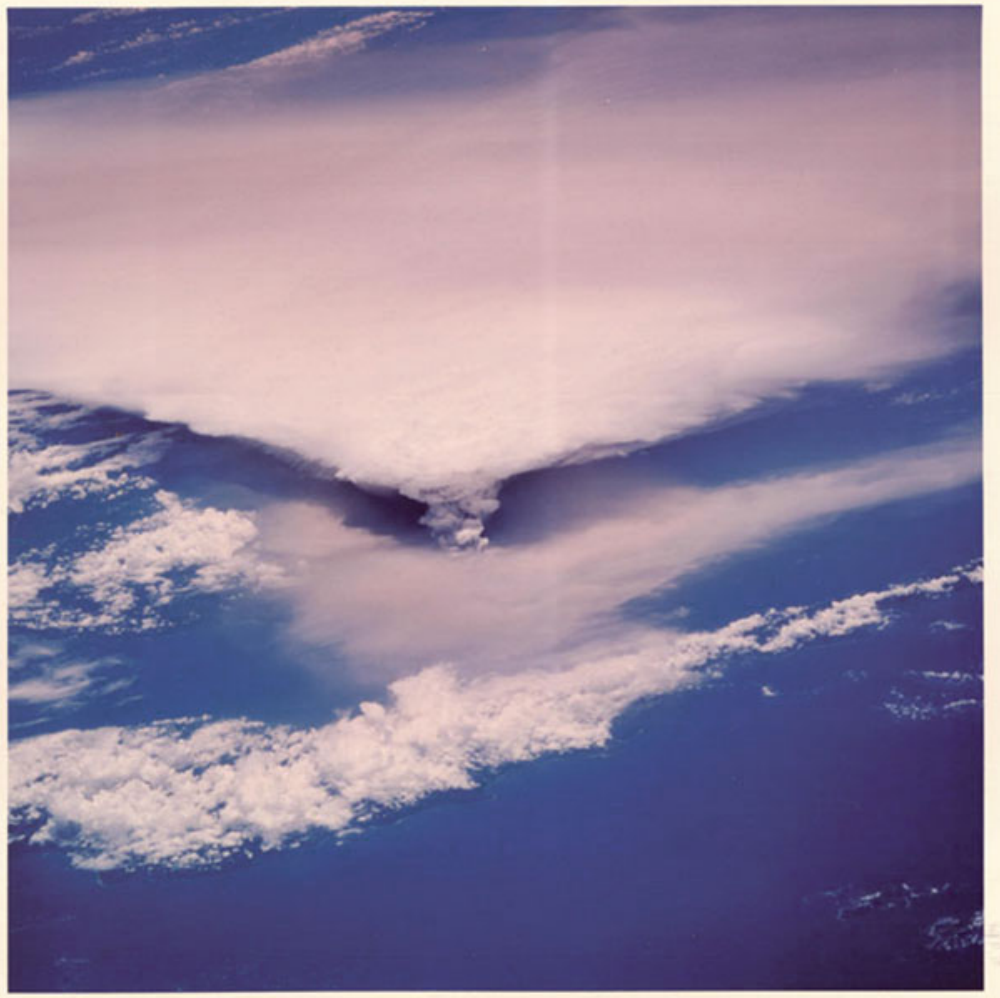

A UNDHA mission to Rabaul in February 1995 (Tomblin and Chung 1995) reported that "the Rabaul Emergency Plan had in most respects worked very well". Analysis of the events and responses of the precursory period and of the first few months of the eruptive period identified problems with telecommunications as one of 22 issues "which could be improved for the future". This issue is discussed further in the next Sect. 6.

While responses to the events of 18-19 September 1994 were not ideal in some instances, the general recognition of the impending eruptive threat, the implementation of emergency plans, the willingness of most people to evacuate and the successful evacuation of areas of greatest danger resulted in avoidance of a repeat of the outcome of Vulcan's 1937 eruption and of the sort of tragedy that befell the town of Armero during the 1985 Nevado del Ruiz volcano catastrophe. At Armero, the loss of $>22,000$ lives was attributed mainly to "cumulative human error-misjudgement, indecision and bureaucratic shortsightedness" (Voight 1990, p. 383).

An irony of the 1994 eruption is the extent of damage to Rabaul Town ( $70 \%$ destroyed) from the relatively small volume of Tavurvur tephra emissions $\left(40 \times 10^{6} \mathrm{~m}^{3}\right)$. The output from Vulcan was much greater $\left(260 \times 10^{6} \mathrm{~m}^{3}\right)$ but its impact was mostly in the vicinity of Vulcan itself. Several (evacuated) villages were obliterated by the pyroclastic flows and heavy tephra fall from Vulcan. The damage from Tavurvur tephra was maximized by the close proximity of Rabaul Town to Tavurvur and by the prevailing winds which carried the tephra directly towards the town. Such seemingly disproportionate impact was also evident at (the snow and ice covered) Nevado del Ruiz Volcano in 1985 where $<5 \times 10^{6} \mathrm{~m}^{3}$ of magma ejected as pyroclastic flows was able to generate about $60 \times 10^{6} \mathrm{~m}^{3}$ of lahars from 10 to $20 \times 10^{6} \mathrm{~m}^{3}$ of melt water (Calvache 1990; Pierson et al. 1990). 
Real-time monitoring capability for both earthquake locations and seismic amplitudes (RSAM-Murray and Endo 1989) was deployed at Rabaul in October 1994 by a team from VDAP-USGS, replacing the damaged and seriously weakened existing seismic network. At the same time new electronic tiltmeters were also installed. High resolution GPS monitoring commenced in 1999 with sensors deployed at Matupit Island and at RVO. All of the immediate efforts to restore and upgrade volcano-monitoring facilities at Rabaul focussed on data transmission to RVO. Subsequently, plans were developed for a re-location of the volcano-monitoring hub to Kokopo, and in 2016 the first element (accommodation block) of a re-located volcano observatory had been completed.

In general, the scientists who visited Rabaul during the eruptions followed the principles of not engaging in discussions with local media and individuals, and releasing information only through official channels i.e. RVO and PIU. However, in one case a visiting scientist caused significant anxiety through public discussions of a personal prediction of increased volcanic activity during the second week of the eruptions.

Negative outcomes of the eruptions include: losses of lives, homes, property, businesses and livelihoods. Many people suffered significant financial loss. Some of these losses were a result of the inability to get adequate insurance because premiums had been raised due to the 1983-85 Crisis Period. The displacement of 105,000 people during the first weeks of the eruptions created a huge logistical problem of providing food, water and shelter in care centres. The number of displaced people was swelled by the unnecessary movement of some people from safe area locations to care centres. Probably this was driven by fear of the unknown while care centres offered the perception of "safety in numbers", the provision of food and water, and access to information about the unfolding drama. For some, the displacement and disruption continued for many months. The short- and long-term psychological effects of the trauma of displacement and disruption were largely not addressed officially.

\section{Lessons}

The 1994 eruptions at Rabaul, which destroyed much of the town and several villages (Fig. 15), were remarkable for the very small loss of life. This outcome resulted from timely evacuations from areas most impacted by volcanic activity. Nevertheless, the rapid development of the late-stage precursory activity caught most residents by surprise, allowing insufficient time to pack up properly, with the result that many small businesses are no more and many people lost all possessions.

Experiences during the long period of precursory activity and during the 1994 eruptions, and comparisons with experiences during the 1937 eruptions and earlier activity, have framed the following lessons:

\section{Volcanic crises and unrest are common at Rabaul}

Historical records suggest that volcanic crises and unrest are common between eruptions at Rabaul. Most, if not all, of the volcanic crises at Rabaul follow a similar pattern. The earthquakes of crises are of high frequency type and the strongest events occur near the beginning of a crisis to be followed by a sequence of smaller earthquakes. Typically, uplift of parts of the caldera floor occurs during crises in association with the earthquake activity. Greater and more rapid uplift accompanies the sustained strong seismicity that occurs immediately before an eruption outbreak. Tsunami are generated by the stronger crises, particularly those immediately preceding eruptions.

\section{An individual crisis may or may not lead directly to an eruption.}

In terms of maximum earthquake magnitude, there was nothing to distinguish the crisis that immediately preceded the 1994 eruption from earlier crises. Caldera earthquakes of magnitude $\left(\mathrm{M}_{\mathrm{L}}\right) 4.9$ or greater occurred on at least 4 occasions (Mori et al. 1989) before the magnitude $\left(\mathrm{M}_{\mathrm{L}}\right) 4.9$ and 5.1 events of the Ultimate Crisis in 


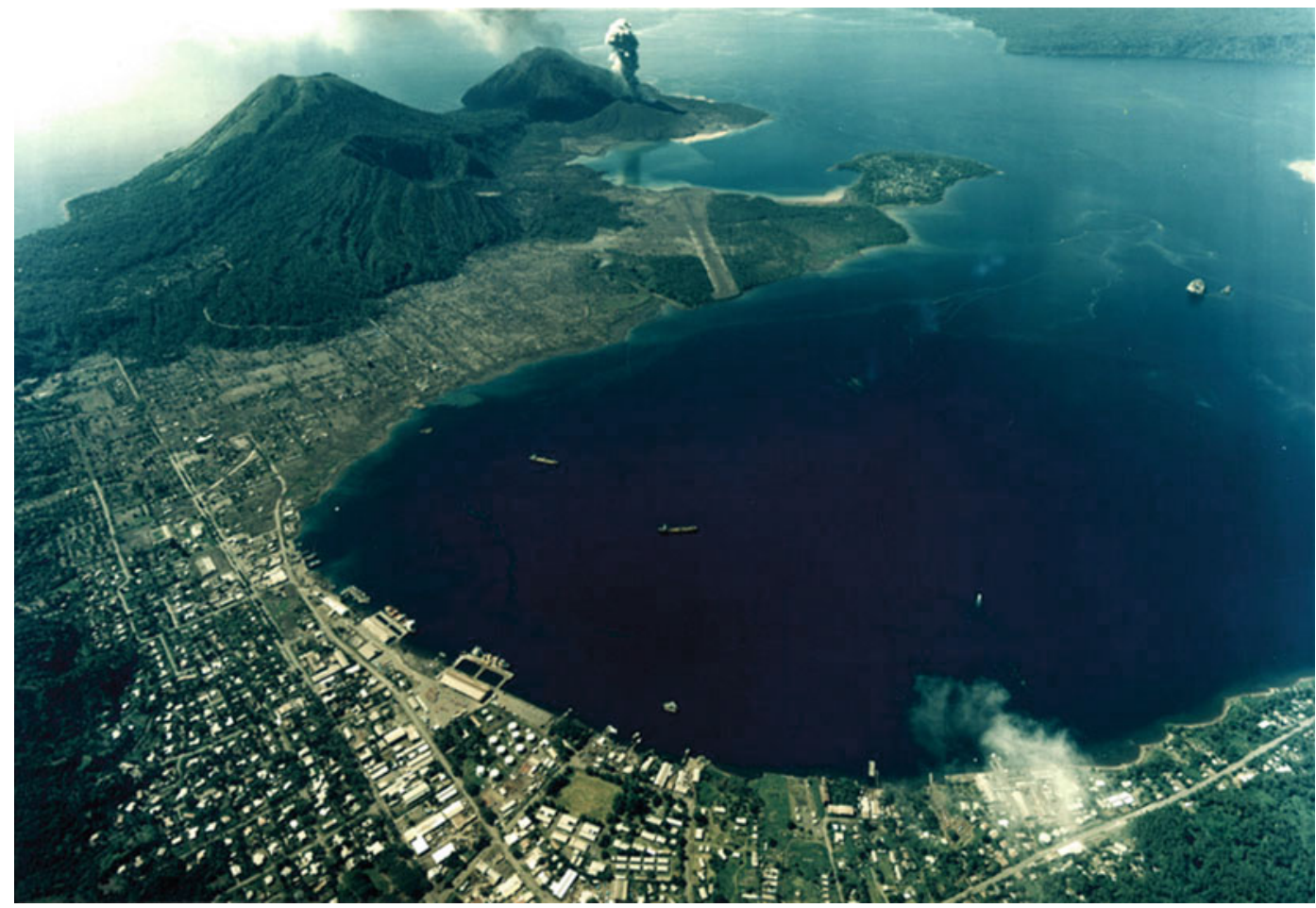

Fig. 15 Aerial view of Rabaul Town from the northwest in early January 1996 showing destruction of the southern and central parts of the town area. A small eruption cloud stands over Tavurvur. The neighbouring stratovolcanoes

1994 (Table 1). These events were: October $1980-\mathrm{M}_{\mathrm{L}}$ 5.2, March 1982- $\mathrm{M}_{\mathrm{L}}$ 5.1, March $1984-\mathrm{M}_{\mathrm{L}}$ 5.1, October $1984-\mathrm{M}_{\mathrm{L}}$ 4.9. However, the sustained high rate of felt earthquake occurrence in $27 \mathrm{~h}$ periods preceding the 1937 and 1994 eruptions was distinctive compared with other crises.

\section{Late stage precursory activity can develop rapidly}

Late stage precursory activity developed rapidly in 1994: only 27 h separated the start of the final crisis and the outbreak of eruptions. There was a re-intensification of seismicity 14$16 \mathrm{~h}$ after the initial strong earthquakes. The resurgence of seismicity halfway through the immediate pre-eruption crisis was associated
Turagunan, Kabiu and Palangiangia are looming threatsall were active in the Middle-Late Holocene. Photo courtesy of Gazelle Restoration Authority, Kokopo, East New Britain

with the rapid uplift of parts of the caldera floor that began less than $12 \mathrm{~h}$ before the start of the 1994 eruptions. Memories and stories of a similar pattern of late-stage precursory activity that preceded the 1937 outbreak influenced the responses of traditional communities to the events of 1994.

\section{Eruptions can occur at more than one vent}

In the three most recent eruptive periods, 1878, 1937 and 1994, two vents on opposite sides of Rabaul Caldera erupted simultaneously. This pattern of activity has implications concerning the stability of Rabaul Volcano. Simultaneous activation of different parts of the volcanic system could lead to major de-stabilization, culminating in events of significantly larger scale. 


\section{Seismic data acquisition needs to be automated}

A microfilm and paper chart seismic recording system was deployed through most of the 23 years of precursory activity and for about 10 days into the 1994 eruptions. Processing of data in this system involved manual timing of earthquakes and manual entry of data into a computer for locating the earthquakes. This system provided no facility for monitoring seismic amplitudes. The system was adequate for routine operations in non-eruptive periods when the most intense activity was isolated crises, but could not cope with a sustained high-intensity crisis or eruptions outbreak. Real-time monitoring capability for both earthquake locations and seismic amplitudes is essential.

\section{Continuous real-time telemetered ground deformation monitoring is required}

Remarkable ground deformation occurred on the night before the 1994 eruptive outbreak but was not observed. Telemetering electronic tiltmeters and tide gauges had been deployed at Rabaul as a result of the 1983-85 Crisis Period but had become unoperational by 1994 because of maintenance and funding difficulties. If operational, these instruments may have provided an earlier warning that an eruption was imminent.

\section{Clear established links with media are needed}

The experience of the Crisis Period in 198385 demonstrated the advantages of having a Public Information Unit to disseminate information from scientists and civil defence officials and to handle all media enquiries about volcanic activity. This allowed the scientists to concentrate on volcano monitoring. Nevertheless, it is desirable for scientists to communicate directly with media, if the circumstances permit.

\section{Strong communication links between scien- tists and civil defence agencies are needed}

Serious communications difficulties between scientists and civil defence officials were encountered during the first dew days of the 1994 eruptions because of the loss of telephone services. In order to ensure effective and reliable official communications it is necessary to have multiple communications links, including radios and both mobile and landline telephones. Protection and duplication of communications infrastructure, such as telephone exchanges, is essential.

\section{Logistical arrangements for volcano moni- toring teams and civil defence personnel need careful planning}

At Rabaul in 1994 volcanologists and disaster co-ordinators were also victims of the eruptions and had to deal with a number of logistical issues, including care of families, accommodation, security, protection of property and emergency communications. This had a heavy impact on the ability of these officials to function effectively during the early days of the 1994 eruptions.

\section{Protection of Property}

One disturbing aspect of both the 1937 and 1994 eruptions was looting. In 1994 looting started on the night before the eruptions began, when there was a mass evacuation of Rabaul. In 1937 vigilante groups patrolled the town and severely punished looters. This did not happen in 1994 and during the first few days and weeks of the 1994 eruptions looting took place on a large scale, essentially unchallenged. The looting was a serious distraction for RVO staff and emergency officials who were residents of Rabaul Town and whose homes and possessions were targeted by looters. 


\section{Concluding Remarks}

1. Living near active and potentially-active volcanoes requires open and effective lines of communication between volcano specialists, national and provincial government officials, town authorities and the general public. Communication between all of these sectors is vital at all stages of volcano surveillance, eruption contingency planning, town planning and disaster management. The creation of the PIU by the East New Britain Provincial Government in 1984 assisted greatly in the dissemination of volcano-related information.

2. The availability of volcano contingency plans provides great support during crisis periods. Involvement of all sectors of threatened communities in the creation of these plans is desirable. Frequent rehearsals and reviews of the plans maintains a high level of alertness.

3. A majority of the various communities of the Rabaul area coped well with the prospect of impending eruption once they were provided with relevant information. This information coupled with local knowledge and lessons from previous eruptions, particularly that of 1937, resulted in a high level of volcano awareness that led to decisive actions to evacuate the most-threatened areas during the immediate pre-eruption period. For some, "actions may have spoken louder than words", as some residents may have been influenced to evacuate by the movements of others around them, resulting in a mass exodus of people from within the caldera.

Acknowledgements The manuscript benefitted greatly from the detailed reviews by Professor Emeritus Russell Blong and Dr. Simon Day. Marissa Sari Egara of the Port Moresby Geophysical Observatory helped with word processing of the manuscript. Sonick Taguse of Papua New Guinea's Mineral Resources Authority helped with preparation of some of the line diagrams. COM and II publish with the permission of the Secretary, Mr. Shadrach Himata, Department of Mineral Policy and Geohazards Management, Papua New Guinea.

\section{References}

Almond RA, McKee CO (1982) Location of volcano-tectonic earthquakes within the Rabaul Caldera. Geological Survey of Papua New Guinea Report $82 / 19,10 \mathrm{p}$

Ando M, Ishida M, Hayashi Y, Mizuki C, Nishikawa Y, Tu Y (2013) Interviewing insights regarding the fatalities inflicted by the 2011 Great East Japan Earthquake. Nat Hazards Earth Syst Sci 13(9):21732187

Blong R, McKee CO (1995) The Rabaul eruption: destruction of a town. Natural Hazards Research Centre, Macquarie University

Boegershauser G (1937) Eruption of a volcano at Rabaul. Rabaul Times 35:15 (6 Aug 1937)

Brown G (1878) Journal of the Rev. G. Brown 18601902 (11 volumes). Mitchell Library, Sydney, Australia

Calvache VML (1990) Pyroclastic deposits of the November 13, 1985 eruption of Nevado del Ruiz volcano, Colombia. In: Williams SN (ed) Nevado del Ruiz Volcano, Colombia, I. J Volcanol Geotherm Res 41:67-78

Chouet BA, Page RA, Stephens CD, Lahr JC, Power JA (1994) Precursory swarms of long-period events at Redoubt Volcano (1989-1990) Alaska: their origin and use as a forecasting tool. J Volcanol Geoth Res 62:95-135

Cooke RJS (1977) Rabaul Volcanogical Observatory and geophysical surveillance of the Rabaul Volcano. Aust Phys Feb 1977, pp 27-30

Davies H (1994) The 1994 eruption of Rabaul Volcanothe events of 18-19 September 1994. Report prepared for ENB Provincial Disaster Committee (unpublished)

Davies H (1995) The 1994 eruption of Rabaul volcano-a case study in disaster management. Report prepared for the UNDP Office Port Moresby (unpublished), $35 \mathrm{p}$

Dent AW, Davies G, Barret P, de Saint Ours PJA (1995) The 1994 eruption of the Rabaul volcano, Papua New Guinea: injuries sustained and medical response. Med J Aust 163(4/18):635-639

Faria B, Fonseca JFBD (2014) Investigating volcanic hazard in Cape Verde Islands through geophysical monitoring: network description and first results. Nat Hazards Earth Syst Sci 14:485-499

Fisher NH (1939) Geology and vulcanology of Blanche Bay, and the surrounding area, New Britain. Territ $\mathrm{N}$ Guin Geolog Bull 1, 68 p

Fisher NH (1976) 1941-42 eruption of Tavurvur Volcano, Rabaul, Papua New Guinea. In: Johnson RW (ed) Volcanism in Australasia. Elsevier, Amsterdam, pp 201-210

Ghasemi H, McKee C, Leonard M, Cummins P, Moihoi M, Spiliopoulos S, Taranu F, Buri E (2016) Probablistic seismic hazard map of Papua New Guinea. National Hazards. doi:10.1007/s11069-0152116-8 
Greene HG, Tiffin DL, McKee CO (1986) Structural deformation and sedimentation in an active caldera. J Volcanol Geotherm Res 30:327-356

Heming RF (1974) Geology and petrology of Rabaul Caldera, Papua New Guinea. Geol Soc Am Bull $85: 1253-1264$

Itikarai I (2008) The 3-D structure and earthquake locations at Rabaul Caldera, Papua New Guinea, M. Phil. Thesis. The Australian National University

Johnson RW, Threlfall NA (1985) Volcano Town-the 1937-43 eruptions at Rabaul. Robert Brown and Associates, Bathurst

Johnson RW, Everingham IB, Cooke RJS (1981) Submarine volcanic eruptions in Papua New Guinea: 1878 activity of Vulcan (Rabaul) and other examples. In: Johnson RW (ed) Cooke-Ravian volume of volcanological papers. Geol Surv Papua New Guinea Memoir 10:167-179

Lahr JC, Chouet BA, Stephens CD, Power JA, Page RA (1994) Earthquake classification, location and error analysis procedures for a volcanic sequence: application to 1989-1990 eruptions of Redoubt Volcano, Alaska. J Volcanol Geotherm Res 62:137-151

Lindley ID (1995) The 1994-1995 Rabaul volcanic eruptions: human aspects. R Soc NSW Bull 188 (Part 1), 189 (Part 2) and 190 (Part 3)

McKee CO (1981) Recent eruptive history of the Rabaul volcanoes, present volcanic conditions and potential hazards from future eruptions. Geological Survey of PNG Report 81/5

McKee CO, Mori J, Talai B (1989) Microgravity changes and ground deformation at Rabaul Caldera, 19731985. In: Latter JH (ed) IAVCEI proceedings in volcanology, vol 1. Volcanic hazards. Springer, Berlin, pp 399-428

McKee CO, Patia H, Kuduon J (2016) Recent eruption history at Rabaul: volcanism since the 7th century AD caldera-forming eruption. Geohazards Management Division Report 2016/01

McKee CO, Lowenstein PL, de Saint Ours P, Talai B, Itikarai I, Mori JJ (1984) Seismic and ground deformation crises at Rabaul Caldera: prelude to an eruption? Bull Volcanol 47-2:397-411

McKee CO, Johnson RW, Lowenstein PL, Riley SJ, Blong RJ, de Saint Ours P, Talai B (1985) Rabaul Caldera Papua New Guinea: volcanic hazards, surveillance and eruption contingency planning. J Volcanol Geotherm Res 23:195-237

Mori J, McKee CO (1987) Outward-dippingring-fault structure at Rabaul Caldera as shown by earthquake locations. Science 235:193-195

Mori J, McKee C, Itikarai I, Lowenstein PL, Talai B (1986) Account and interpretation of the seismicity during the Rabaul Seismo-deformational crisis
September 1983 to July 1985 . Geological Survey of Papua New Guinea Report 86/26

Mori J, McKee CO, Itikarai I, Lowenstein PL, de Saint Ours P, Talai B (1989) Earthquakes of the Rabaul seismo-deformational crisis September 1983 to July 1985: Seismicity on a caldera ring fault. In: Latter JH (ed) IAVCEI proceedings in volcanology, vol 1. Volcanic hazards. Springer, Berlin, pp 429-462

Murray TL, Endo ET (1989) A real-time seismic amplitude measurement system (RSAM). U.S. Geological Survey Open File Report 89-684, 25 p

Neumann K (1996) The 1994 volcanic disaster in East New Britain and its aftermath: comments and observations. Department of Archaeology and Anthropology, Australian National University ISBN 0642 25077 4, $30 \mathrm{p}$

Newhall CG, Dzurisin D (1988) Historical unrest at large calderas of the world. US Geol Surv Bull 1855 2:1108

Nishimura Y, Nakagawa M, Kuduon J, Wukawa J (2005) Timing and scale of tsunamis caused by the 1994 Rabaul Eruption, East New Britain, Papua New Guinea. In: Satake K (ed) Tsunamis: case studies and recent developments. Springer, Dordrecht, pp 43-56

Pierson TC, Janda RJ, Thouret J-C, Borrero CA (1990) Perturbation and melting of snow and ice by the 13 November 1985 eruption of Nevado del Ruiz, Colombia and consequent mobilization, flow and deposition of lahars. In: Williams SN (ed) Nevado del Ruiz Volcano, Colombia, I. J Volcanol Geotherm Res 41:17-66

Ripper ID, Letz H, Anton L (1996) Seismicity and seismotectonics of Papua New Guinea presented in earthquake depth zones. Geological Survey of Papua New Guinea Report 96/9

Sack P, Clark D (1983) Eduard Hernsheim South Sea Merchant. Institute of Papua New Guinea Studies, $230 \mathrm{p}$

Stewart RC, Itikarai I (in prep.) Seismic activity associated with the 1994-95 eruption of Rabaul Volcano

Tomblin J, Chung J (1995) Papua New Guinea, analysis of lessons learnt from Rabaul volcanic eruptions and programming for disaster mitigation activities in other parts of the country. UNDHA Report on Mission from 17 to 26 February 1995

United Nations (1977) Disaster prevention and mitigation, vol 1: volcanological aspects

Voight B (1990) The 1985 Nevado del Ruiz volcano catastrophe: anatomy and retrospection. J Volcanol Geotherm Res 42:151-188

Walker GPL, Heming RF, Sprod TJ, Walker HR (1981) Latest major eruptions of Rabaul Volcano. In: Johnson RW (ed) Cooke-Ravian volume of volcanological papers. Geol Surv Papua New Guinea Memoir 10:181-193 
Open Access This chapter is licensed under the terms of the Creative Commons Attribution 4.0 International License (http://creativecommons.org/licenses/by/4.0/), which permits use, sharing, adaptation, distribution and reproduction in any medium or format, as long as you give appropriate credit to the original author(s) and the source, provide a link to the Creative Commons license and indicate if changes were made.
The images or other third party material in this chapter are included in the chapter's Creative Commons license, unless indicated otherwise in a credit line to the material. If material is not included in the chapter's Creative Commons license and your intended use is not permitted by statutory regulation or exceeds the permitted use, you will need to obtain permission directly from the copyright holder. 